Pamiętnik Literacki 2019, 1, s. 113-138

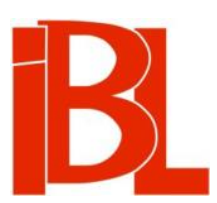

\title{
Zadomowieni w literaturze. $O$ czytaniu pisarzy
}

Katarzyna Buszkowska 
Pamiętnik Literacki CX, 2019, z. 1, PL ISSN 0031-0514

DOI: $10.18 .318 /$ PL.2019.1.7

KATARZYNA BUSZKOWSKA Instytut Badań Literackich PAN, Warszawa

ZADOMOWIENI W LITERATURZE O CZYTANIU PISARZY

Najpierw czytałem jak nakręcony ${ }^{1}$.

Na prozę Jerzego Pilcha i Andrzeja Stasiuka zazwyczaj patrzy się przez pryzmat miejsca - wybranego i tego, do którego się dociera, które się odnajduje, którego się szuka. Nie mniej przestrzeni w ich twórczości zajmuje motyw lektury książek. $Z$ pozoru odpowiedź na pytanie, do czego pisarz używa literatury, wydaje się prosta i sprowadza się do odkrywania sensu oraz do warsztatu. W tym przypadku źródeł można dopatrywać się w dewizie romantycznej: „żyć, jak się pisze”, która prowadzi do uznania, że to sztuka daje ukojenie, jest azylem dla świata, który znika. Romantycy uczynili czytanie fundamentem swojej egzystencji, rodzajem hermeneutyki służącej do tego, by odsłonić sens zaklęty w książkach czy otaczającej ich rzeczywistości. W potocznym sformułowaniu „uprawianie literatury” kryje się właśnie to, co dla niektórych ludzi pióra staje się jedynym możliwym sposobem istnienia. $\mathrm{Pi}$ sanie - mimo że mozolne, obowiązkowe, postrzegane jako zawód - stanowi swoiste święto, obrzęd wymagający przygotowań, samozaparcia, wyrzeczeń, będący celebrowaniem aktu twórczego. Czytanie zaś jest elementem codzienności, kluczowym aspektem poprzedzającym pisanie. Stylem życia.

Na pierwszy rzut oka wydaje się, że każdy pisarz czyta innych pisarzy, że cała literatura to rozmowa $z$ tekstami już istniejącymi. W tym artykule przyglądam się grupie ludzi pióra, którzy w dorosłość - i w tworzenie literatury, w myślenie o niej wchodzili u schyłku lat osiemdziesiątych XX wieku, kiedy królowała muzyka rockowa (ale tylko jako wentyl bezpieczeństwa), a kultura i sztuka stanowiły terytorium odkrywania własnej podmiotowości. Każdy z pisarzy, o których będzie tu mowa - Jerzy Pilch, Janusz Anderman, Stefan Chwin, Zbigniew Mentzel, Andrzej Stasiuk $^{2}$ - w czytaniu od początku szukał azylu wolności, a stopniowo - także

1 Schizofrenia, labilność - z tego składa się człowiek. R. Sław oń rozmawia z A. S ta si u ki e m. „Harper's Bazaar” 2018, nr 4, s. 69.

2 Wymienieni twórcy w latach osiemdziesiątych i dziewięćdziesiątych XX wieku stawali się pisarzami - choć nie zawsze jeszcze publikowanymi. J. Anderman zaczą najwcześniej, najszybciej też osiągnął rozgłos - jego debiut w 1976 roku (Zabawa w głuchy telefon) odbył się pod czujnym okiem propagatora „rewolucji artystycznej”, H. Berezy. Zauważony i doceniony za kunszt języka, Anderman za swoją drugą powieść, Gra na zwłokę (1979), otrzymał Nagrodę Fundacji im. Kościelskich J. Pil ch rozpoczął karierę literacką jako 16-latek, w 1969 roku, publikując swój pamiętnik 
osobistego sposobu dookreślenia się w relacji ze światem, potwierdzania wyznawanych wartości w obliczu fluktuującej prawdy. W przypadku tych artystów zamiast: „kim jesteś?”, można zapytać: „skąd pochodzisz?” i „co cię literacko określa?” W literaturze odnaleźli oni swoje miejsce. To opowieść o stawaniu się pisarzem w toku zmian społeczno-politycznych, które doprowadziły do rekonfiguracji kultury ${ }^{3}$. Interesuje mnie próba rekonstrukcji „reguł wytwarzania świata” ${ }^{4}$, odpowiedź na pytanie, jakimi metodami autorzy dokonują tego zakotwiczenia się w rzeczywistości.

Pilch i Stasiuk - obaj czytają tych samych pisarzy. Do ich kanonu wielkich należą: Thomas Mann, Vladimir Nabokov, Andriej Płatonow, Émile Cioran, Samuel Beckett, Adam Mickiewicz, Tadeusz Konwicki. Ironia i melancholia - bliskie sobie temperamenty, bo łączą dystans ze świadomością tego, co w zaniku; potrzebie ekspresji przypominają o tęsknocie za naiwnością, za dziecięcym zachwytem nad światem-księgą: możliwym do odczytania, do zrozumienia, wreszcie do spełnienia.

Po co jest lektura? Co daje Pilchowi w chorobie powtórne czytanie klasyków? W Dzienniku (2012) powtarza on, że wraca do nich jak do rodzinnej Wisły. O swoich lekturach pisał zresztą od początku. W Bezpowrotnie utraconej leworęczności wspominał, jak czyta „Z większym niż dawniej zrozumieniem” Pana Tadeusza Mickiewicza i Martwe dusze Nikołaja Gogola ${ }^{5}$. Bohater Miasta utrapienia (2004), Patryk,

na łamach tygodnika „Na Przełaj”. W roku 1975 w pokonkursowym tomie wydanym przez „Czytelnika” obok utworów Andermana, B. Zadury, E. Stachury znalazło się opowiadanie W korcu ma$k u$ Pilcha. Rys jego charakterystycznej później prozatorskiej śmiałości, ujawnił się po raz pierwszy w interpretacji wierszy J. Trznadla, zamieszczonej w 1976 roku w miesięczniku „Poezja”. Prawdziwa sławę w latach osiemdziesiątych Pilch zyskał dzięki felietonom wygłaszanym na spotkaniach organizowanych przez redakcję podziemnego mówionego magazynu literackiego „NaGłos” (w 1990 roku pismo zaczęło ukazywać się w druku). Jako autor prozy Pilch zadebiutował dopiero w 1988 roku zbiorem opowiadań zatytułowanym Wyznania twórcy pokatnej literatury erotycznej (pierwsze z nich datowane jest na rok 1980) i od razu przypadła mu w udziale Nagroda Fundacji im. Kościelskich. S. Chw in najpierw został badaczem literatury i krytykiem, znawca romantyzmu, kultury, wielbicielem poezji Cz. Miłosza; pisarzem na początku był jakby przy okazji. Jako naukowiec debiutował w 1975 roku artykułami „Trans-Atlantyk” wobec „Pana Tadeusza” („Pamiętnik Literacki”, z. 2) oraz Gombrowicz - sarmata kontestujący („Ruch Literacki”, nr 4). W roku 1981 wraz z S. Rośkiem wydał książkę eseistyczną Bez autorytetu (za którą w 1983 roku otrzymali obaj Nagrodę Fundacji im. Kościelskich). W roku 1985 pod pseudonimem Max Lars opublikował powieść fantastyczną Ludzie-skorpiony. Przygody Joachima El Toro na wyspach archipelagu San Juan de la Cruz. W pełni literacki popis dał w 1991 roku jako autor książki Krótka historia pewnego żartu. (Sceny z Europy Środkowowschodniej).

Z. Me ntzel w latach osiemdziesiątych współpracował z londyńskim wydawnictwem „Puls”, dla którego wybierał i redagował prozę m.in. Andermana czy Pilcha. Jego felietony oraz zapiski z ostatnich kwartałów schyłkowego PRL-u wyszły jako jego pierwsza książka, zatytułowana Pod kreska, zaraz po przełomie 1989 roku.

A. Sta siuk - młodszy o dekadę od wymienionych autorów - w 1992 roku opublikował Mury Hebronu (utwór powstał już w 1985 roku na zamówienie niszowego wydawnictwa nie związanego z oficjalnym obiegiem). Jeszcze wcześniej, w 1990 roku, w piśmie „Po Prostu” zamieścił Stasiuk wiersz Nie miewam wizji. Nagrodę Fundacji im. Kościelskich - na przełomie lat osiemdziesiątych i dziewięćdziesiątych będąca wyznacznikiem sukcesu literackiego i uznania krytyki - dostał za Biatego kruka (1995).

3 Zob. M. Ho p fing e r, Literatura i media po 1989 roku. Warszawa 2010.

4 Określenie zapożyczone od L. B u r s k i ej (Awangarda i inne złudzenia. O pokoleniu '68 $w$ Polsce. Warszawa 2012).

5 J. Pilch, Bezpowrotnie utracona leworęczność. Wyd. 2. Kraków 2001, s. 34. 
odtwarza historie poznania się własnych rodziców na przedstawieniu Dziadów w reżyserii Konrada Swinarskiego, cofa się też myślą do ojcowskiej recytacji wiersza Mickiewicza Śniła się zima. Stasiuk z kolei wpatruje się w zdjęcie Płatonowa, które dostał zreszta od Pilcha, też urzeczonego pisarstwem Rosjanina ${ }^{6}$. Autor Opowieści galicyjskich nie może również oderwać wzroku od portretu Becketta ${ }^{7}$. Oryginalne świadectwo żywego stosunku Stasiuka do polskiej poezji romantycznej stanowi płyta nagrana w roku 2018, wspólnie z ukraińskim zespołem rockowym: Mickiewicz - Stasiuk - Haydamaky, na której pisarz recytuje 6 wierszy z cyklu Sonety krymskie, Alpuhare z Konrada Wallenroda, balladę Upiór, Redutę Ordona i jeden z liryków lozańskich [Pytasz, za co Bóg...]. W wywiadzie z tego okresu Stasiuk mówił o ponowym czytaniu Mickiewicza oraz wspominał swoją sprzed lat lekturę Dziadów ${ }^{8}$.

Przywiązaniu do literatury towarzyszy drążenie sensu, odkrywanie zasady świata, szukanie zrozumienia i wtajemniczenia w coś, co przemienia jednostkowe doświadczenie we wspólnotę. Namiętność czytania zbliża Pilcha i Stasiuka do romantyków, o których tak pisał Zygmunt Łempicki:

Czytanie jest dla ruchu romantycznego po prostu aktem fundamentalnym, ową funkcją, dzięki której dokonuje się asymilacja materiału potrzebnego romantykom do życia i działania ${ }^{9}$.

Pilch czyta niezmordowanie, konfrontuje światy i modele lektury, idzie za tekstem, ale jednocześnie szuka śladów „wymykania się” intencji autora, próbuje wniknąc w sens ukryty pomiędzy słowami, by wreszcie to, co objawia się w lekturze, uczynić własnością swojej świadomości. Podobnie Antoni Libera - w lekturze uwidacznia się najpełniej jego obsesja wczepiania się w znaczenie, które wyzwala opowieść z lokalnych realiów i nadaje jej wymiar uniwersalny. Mentzel podsumuje najtrafniej:

„Wielcy filozofowie” potrzebni są filozofom, tak samo jak „wielcy pisarze” potrzebni sa pisarzom jako ich własna „prehistoria”, jako „wtórna pamięć”, jako „konieczny składnik człowieczeństwa”. Bez tych „wielkich" i bez ich Arcydzieł świat jest niewyobrażalny $[\ldots]^{10}$.

Wyłania się z tego także perspektywa odbiorcy. U Pilcha najwięcej zyska ona

6 O fascynacji tym zdjęciem pisał w połowie lat dziewięćdziesiątych J. Pilch (Tezy o głupocie, piciu i umieraniu. Kraków 2003, s. 176): „Od prawie dwudziestu lat na ścianie w moim pokoju wisi fotografia Andrieja Płatonowa. Lektura Płatonowa była to moja największa literacka emocja, najgłębsze przeżycie, najsilniejszy - dech zapierający - zachwyt. [...] Dziesiątki razy przymierzałem się do pisania o Płatonowie i nigdy mi się to nie udawało. Nie umiałem odgadnąć zaklęcia, po wypowiedzeniu którego wszystko staje się jasne. Nie potrafiłem nazwać sekretu tego genialnego pisarstwa, nie potrafiłem rozgryźć zatrważającego układu jego frazy”.

7 Zob. A. Sta si u k, Twarz Samuela Becketta. „Kwartalnik Artystyczny” 1996, nr 4. Dowodem tej fascynacji literackiej jest także sztuka A. St a s i u ka Czekając na Turka (Wołowiec 2009), która nawiazuje tytułem do najbardziej znanego utworu irlandzkiego dramaturga.

8 Zob. Schizofrenia, labilność - z tego składa się człowiek, s. 69.

9 Z. Łe m p i cki, Świat ksiażek i świat rzeczywisty. Przyczynek do ujęcia istoty romantyzmu. Przeł.

O. Dobijanka. W: Renesans, oświecenie, romantyzm $i$ inne studia z historii kultury. Przedm.

B. Su ch od olski. Warszawa 1966, s. 350.

10 Z. Mentze1, Laufer. Londyn 1998, s. 179. Autor nawiązuje w tym miejscu do tekstu L. Kołak o w s ki e go „Wielki Filozof” jako kategoria historyczna (w zb.: Księga pamiatkowa ku czci profesora Tadeusza Kotarbińskiego $w$ osiemdziesiąta rocznicę urodzin. Oprac. T. C z ė̇o w s k i [i in.] Warszawa 1967). 
na znaczeniu dopiero przy okazji tworzenia not dziennikowych. Mieniące się ,ja” rzeczywiste kontra ,ja” przedstawione, swiat realny versus świat opisany. Autor Dziennika spróbuje zbadać sferę graniczną, obszar zbliżania się i przenikania dwóch realności: tej odczuwanej fizycznie i tej opowiedzianej, ale i dwóch pamięci, z których pierwsza uwięziona jest w szczególe, przywiązana do konkretu, druga zaś to pamięć wyzwolona - świadectwo niezależności tekstu napisanego i istniejącego poza autorem. Zacznijmy od tezy: Dziennik Pilcha - publikowany najpierw w odcinkach w „Przekroju”, potem w „Tygodniku Powszechnym”, w formie książkowej wydany w 2012 roku w strategii autora ustanawia nowy pakt $z$ odbiorcą. Otóż to, co do tej pory było gra z czytelnikiem, staje się teraz grą o język, szukaniem przełamania rytmicznych zdań. Pilch-narrator próbuje zajrzeć pod powierzchnię wyrazów, rozbić frazę, wyjść poza jej ramy, popatrzeć na nią z odmiennej perspektywy i nazwać inaczej. Uchwycić ów moment kształtowania się własnego języka, zanim wyklują się słowa i stworzą połączenia, zanim dostroi się melodia do finalnego brzmienia słynnej Pilchowej frazy. Pilch od zawsze prowadził grę z językiem, mając świadomość, że nowoczesność ufundowała alergię na patos i powagę. Od początku ironia stanowiła oręż w rozgrywce, w której stawka jest moc oddziaływania słów. Analizując współczesną niechęć do wzniosłości, Zofia Król pisze:

Ściana języka jest niepokonywana. To odkrycie, zasadnicze dla kształtowania się współczesności, prowadzi dalej do przekonania, że skoro słowo nie odnosi się do rzeczy, to używanie języka musi się sprowadzać do niego samego - skoro z językiem nie da się na poważnie, to trzeba prowadzić z nim rodzaj gry i podstępem zdobyć cząstkową choćby moc opisu ${ }^{11}$.

Pilch w pierwszych fragmentach dziennika porwał się na rzecz dla siebie - jako ironisty - niebywała. Postanowił sprawdzić, co wyłania się ze stanu, w którym jeszcze nie panuje ironia. Skoro choroba odmienia życie, to musi wpływać także na język, bo dawnym nie da się już opowiadać. W Drugim dzienniku wydaje się momentami, że rzeczywistość chorującego pełni funkcję soczewki dla tych zapisków, a podmiot - by zaistnieć, by nie roztopić się w cierpieniu, nie pozwolić się unicestwić - toczy walkę o słowa, gdyż tylko w rzeczywistości określonej jakimś mianem, w świecie-do-wypowiedzenia, może żyć i zachować ciąłość. Póki piszesz, póty żyjesz - takie stwierdzenie wielokrotnie powraca w wywiadach, których udzielał autor po wydaniu książkowej wersji Dziennika ${ }^{12}$. I choć to credo było mu bliskie i wcześniej, teraz wybrzmiewa mocniej, w tonacji demonstracyjnej ostateczności. W Dzienniku Pilch przestaje uwodzić czytelnika, zaczyna uwodzić język, usiłując się do

11 Z. Król, Cykady mdlały. „Dwutygodnik.com”. Wyd. 148 (2014, nr 12). Na stronie: http://www. dwutygodnik.com/artykul/5629-powaga-cykady-mdlaly.html (data dostępu: 4 I 2019).

12 Także przed wydaniem Dziennika Pilch powtarzał to niczym mantre, jednak od momentu zdiagnozowania u niego choroby Parkinsona ton jego wypowiedzi brzmi mroczniej, a ironia ma w sobie więcej rozpaczy niż dystansu. Przy okazji rozmów o swoim stanie zdrowia autor Miasta utrapienia wspomina, że najgorsza dla niego byłaby utrata zdolności czytania i myślenia, a trudna do zniesienia staje się niemożność samodzielnego pisania. W wywiadzie przeprowadzonym przez D. W od e c ką (Demony Jerzego Pilcha. „Gazeta Wyborcza” 2013, nr z 15-16 VI, s. 16) na pytanie: „Czy opowieść jest antidotum na samobójcze myśli?”, J. Pilch mówi: „Żyjesz, póki piszesz, żyjesz, póki opowiadasz, żyjesz, póki słuchasz”. Zob. też wcześniejszy wywiad: Gadasz, to żyjesz. Z J. Pi lch e m rozmawia M. Ci chy. „Gazeta Wyborcza” 1998, nr z 18 IX, s. 17. 
niego dobrać, naruszyć jego wypolerowana powierzchnię. Inaczej niż dotąd, nie chce opanowywać chaosu doznań, ale chaotyczność przeżycia zaprzęga w służbę literatury, nie dąży już do swojej wykutej frazy, ale próbuje się od niej odbić, zakłócić jej melodię, odnaleźć inne akordy. I wtedy w tym języku Pilcha najwyraźniej do głosu dochodzi strata, zaprzepaszczanie rzeczy i czasu, poczucie obcości siebie, własnego ciała.

Wcześniej poszukiwanie straconego czasu zamieniało się w analizowanie sposobu, w jaki - posługując się pamięcią jako narzędziem - przetwarzamy przeszłość, żeby pasowała do teraźniejszości. Narrator „gadanej” powieści - Pod Mocnym AnioŁem (2000) - nie tylko uczestniczy w wydarzeniach, o których opowiada, ale jest także stroną zainteresowaną tym, jak się pamięta. Trzeba przypomnieć, że Pilch od początku swojej twórczości świadomie gra kategorią autobiograficzną, bohaterami i narratorami, czyniąc ich podobnymi do samego siebie. Czytelnicy więc dopatrują się w nich cech autora i na każdym ze spotkań dopytują się o relację fikcji literackiej z rzeczywistością. Najwięcej emocji to budziło i najgłośniej brzmiało właśnie przy okazji uhonorowanej nagrodą Nike powieści Pod Mocnym Aniołem, tymczasem język jest w niej dla Pilcha zasłona - ani protagonista Juruś, ani jego alkoholizm, ani dziadek Kubica nie pochodza $z$ realnego świata. W tym utworze słowa zagadują rzeczywistość. Odmiennie niż w dziennikowych zapisach, gdzie Pilch, zbliżając życie i literaturę, przebijając się przez mur słów, wykoleja opowieść. Ta gra - ze sobą, $\mathrm{z}$ biografią, $\mathrm{z}$ literatura - zamienia się $\mathrm{w}$ grę o literaturę, o inną jakość opowieści. W Dzienniku - kiedy choroba zaniku dosięga autora realnie - strata okazuje się życiodajna dla języka. To swoista atrofia jest źródłem zadziwiającego światła komentowała Kazimiera Szczuka ${ }^{13}$. Zanik, poprzez próby ominięcia go, przezwyciężenia choćby na poziomie egzystencjalnym, objawia się tu swoim przeciwieństwem - podkreśleniem właśnie tego, co jest. Choroba staje się u Pilcha wtajemniczeniem w sferę sacrum, w której odsłanianie sensu dokona się z poziomu zamyślenia czy zanurzenia w transcendencji (Boga i języka).

Pilch wraca w Dzienniku do dawnych lektur tak, jak wraca się do dzieciństwa ponownie szukając niegdysiejszego wrażenia, konfrontując wspomnienia $z$ aktualnymi przemyśleniami. Mann, Płatonow, Nabokov, Sándor Márai to dla niego symbole inicjacji w dorosłość pisarską. Sięga do tego, co tworzy powiązanie $z$ tamtym czasem, $\mathrm{z}$ jego intensywnością, której autor kurczowo się trzyma, tak jak z pasją oddaje się fascynacji piłkarskiej - w niej także wybrzmiewa siła przeżyć wspólnotowych.

W Dzienniku czystość frazy kłóci się ze zmąconym charakterem przeżycia, zacierają się kontury, sens objawia się jako tajemnica, niczym duchy wędrujące po świecie albo demony. Wraz ze zmiana języka przeobrażeniu ulega autor opowieści, jego status - zarówno w tekście, jak i w obcowaniu ze światem. Nasuwa się nieuchronnie spostrzeżenie, że ową zmianę wymusza choroba pisarza, jednak nie tylko do niej się to sprowadza. Dziennikowe notatki przynosza refleksje natury metafizycznej, że minione zawsze projektuje przyszłość, a w labiryncie czasu teraźniejszego nie sposób ustalić, co odeszło już bezpowrotnie, a co jeszcze może się

13 K. Szczuka, Dziwne światło. „Książki w Tygodniku” 2012, nr 3/4. Dodatek do „Tygodnika Powszechnego" 2012, nr 20, s. 9. 
zdarzyć. Rodzi się z tej refleksji literatura używająca języka, który nie zastyga w formie, próbuje pomieścić w sobie „to, co nagle przydarzone”. Porządek życia i porządek języka stapiają się w dziennikowych notatkach w jedno. Temu procesowi pisania towarzyszy - jak się wydaje - hermeneutyczne przekonanie, że język jest miejscem, w którym rozbłyska prawda, miejscem, gdzie pojawia się (posłużmy się Stasiukową metaforyka) „prześwit”. Choć to może być jedynie prawda zapisanego tekstu - dla Pilcha będzie ona najważniejsza. W Drugim dzienniku autor-narrator przyznaje, że toczy walkę polegającą na wydobywaniu się z mroku, ufundowanego przez mowę, że próbuje przekroczyć ramy narzucającej się frazy. W codzienności dziennika, czyli w przezroczystości i nieuchwytności życia zamkniętego w składni jezzyka, to ciało staje się miejscem percepcji.

Niewątpliwie, wcześniejsza proza Pilcha realizuje konwencję pisarstwa osobistego, ustanowioną przez Witolda Gombrowicza i Tadeusza Konwickiego. I choć wydaje się, że ta formuła jest czymś nie podlegającym zmianom, autor Mojego pierwszego samobójstwa różni się od poprzedników dygresyjnością swojej prozy; jest ona w sposób ostentacyjny stylistycznie dopracowana i retoryczna. W Dzienniku i Drugim dzienniku mamy do czynienia $\mathrm{z}$ pewnym napięciem między próbą przełamywania stylu a utrwalaniem serialowości własnej prozy ${ }^{14}$. Powtarzające się wątki, frazy, znajomy bohater $z$ ustalonymi fobiami i upodobaniami usiłuje zaskoczyć nas czymś nowym - nie tylko to decyduje o podobieństwie do serialu. Jeszcze bardziej atrakcyjna dla Pilcha i dla odbiorców jego dzieł jest plotka - w świecie jego powieści najchętniej szuka się tego, co umyka normie, a o kolorycie postaci (choćby najlepiej znanych) decyduje to, co ukrywają. Osobliwość jest największą zaletą w świecie Pilcha i głównym obiektem jego fascynacji. Trzeba przy tym podkreślić, że autor ten nie traktuje literatury w prosty sposób jako terapii - w Bezpowrotnie utraconej leworęczności narrator rozwija się w wyniku ciagu utrat, jednak myślenie terapeutyczne zostało ujęte tu parodystycznie. Dopiero w Dzienniku Pilch decyduje, by inaczej potraktować i siebie jako pisarza w momencie kryzysowym, i literaturę jako formę leczenia. To wciąż będzie testowanie siebie oraz literatury w różnych rolach.

Duże znaczenie w omawianej twórczości ma także podejście do rytuałów. Świat odmalowany w prozie Pilcha to rzeczywistość, w której nabierają one wyjątkowej wagi. Nie powinno budzić to zdziwienia, w końcu odwieczna moc rytuału oswaja lęk przed śmiercią. Ten niejawny lęk towarzyszył Pilchowi od początku kariery literackiej, ale dopiero choroba Parkinsona, przyszpilając go w cielesności - odczuwanej jako coś wymykającego się spod kontroli - pozwoliła mu przemówić w inny sposób. Pilch-narrator i Pilch-bohater w Dzienniku są dla Pilcha-pisarza tajemniczy, zaskakujący tak samo jak dla czytelnika. Dzieło więc odsłania się jako coś nowego, choć po staremu Pilch szuka konkretu, zakotwicza się w nim, bo on daje pisarzowi oparcie. W świecie wykreowanym $z$ perspektywy osobistej to epizody decydują o sile opowieści - stwarzają dla niej kontekst, a także zakorzenienie w codzienności. Rozpoznanie siebie jako kogoś rzeczywiście obcego, nad kim nie ma się panowania, stanowi doświadczenie prowadzącego dziennik pisarza. Czerpie on z pamięci oso-

14 Zob. G. Grochows ki, „Ciagi dalsze” Jerzego Pilcha. Literatura, serial i okolice. W zb.: Między sztuka a codziennością. W stronę nowej syntezy (1). Red. M. Hopfinger, Z. Ziątek, T. Żuk ow s ki. Warszawa 2016. 
bistej, w której przeszłość nie biegnie linearnie, przypomina raczej ponakładane na siebie warstwy wspomnień. Trudno rozdzielić, co lokuje się w sferze rzeczywistości, a co przynależy jedynie do opowieści. Mowa jak azjatycka trawa - jeden z ulubionych motywów prozy Pilcha - zarasta znakami.

W Dzienniku - a jeszcze dobitniej w jego ciagu dalszym - widoczna jest pewna bezwzględność, z jaką autor siebie traktuje, która objawia się brakiem sentymentalizmu i niedopuszczaniem współczucia. Robi ona silne wrażenie na czytelniku, zwłaszcza gdy towarzyszy jej przeciwstawna postawa czułości wobec siebie i świata. Obok fizycznego cierpienia, strachu i przerażenia, obok widma śmierci pojawia się instynkt życia, który u Pilcha realizuje się jako, paradoksalnie, zwolnienie tempa i kontemplacja lektury. Dlatego autor Dziennika wielokrotnie przypomina o powrocie do klasyków, o samotnych dniach, a także wieczorach w domu, o pisaniu, o doświadczaniu samotności jako esencji tego, co ściera się z życiem i jego traceniem:

21 kwietnia. [...] Miałeś przeto kolejną niedzielę marzeń - nigdzie nie wychodziłeś, $\mathrm{z}$ nikim nie gadałeś, nikt do ciebie nie dzwonił, żadna psycholka nie szturmowała - pisałeś, czytałeś, przeglądałeś swoje książki, słuchałeś swoich płyt, oglądałeś piłkę nożną, było bosko.

Ale gdzieś koło 17:00, 18:00 wszystko się zachwiało, a nawet skończyło. Nagle krew w żyłach przyspieszyła, nie szło więcej pisać ani czytać, muzyka - nawet słodkie barokowe brzdąkaniny - stała się nie do zniesienia, ekran telewizora świecił jak wieko srebrnej trumny, ani spojrzeć, ani zamknąć.

Jak przed laty mawiali tragicy delirycy: ani siedzieć, ani spać, ani leżeć, ani wstać. Jeszcze kawał dnia i cały wieczór przed toba - jak przeżyć pięć godzin wieczności? Samotność jest dobra, im lepsza, tym ciekawsza, samotność w takich chwilach ma ostrze ${ }^{15}$.

Następny zapis, z 3 V 2013, dotyczy choroby Parkinsona - tam gdzie Pilch nie chce mówić o niej wprost, gdzie unika współczucia, gdzie próbuje po dawnemu zachowywać dystans, niejako udziela jej głosu: omawia i przytacza więc obszerne fragmenty z książki Jürgena Thorwalda Kruchy dom duszy ${ }^{16}$ :

Z górą 130 lat po odkryciu i opisaniu przez wiejskiego lekarza Jamesa Parkinsona dolegającej mu uporczywej telepki, której „diabelski sprawca” znajduje się - jak w desperacji błędnie sądził - w rdzeniu kręgowym, nic się nie zmieniło. Dalej się sypią z czystej spekulacji wynikające błędne diagnozy, dalej doskwiera całkowita bezsilność medycyny i straszą odwrotnie do tej bezsilności proporcjonalnie apokaliptyczne, demonami podszyte wizje choroby.

4 maja

„Chociaż drżączka i sztywność nie zawsze pojawiały się wśród objawów lub też przybierały różne formy, to wszyscy chorzy mieli jedną wspólną cechę: przemożne, często nieobliczalne i chaotyczne zaburzenia zdolności ruchu, witalności i popędów, którym w końcu podlegały zdolność czucia i myślenia. Zmęczenie, głębokie otępienie, zwiotczenie porażały chorych; niektórzy z nich spędzali godziny, dni i tygodnie bez ruchu na ławce czy krześle, niezdolni bronić się przed siłą odczuwaną jako coś "obcego" we własnym wnętrzu. Ich mięśnie zdawały się zablokowane i poddawały się ich woli niechętnie. Nogi i ręce sprawiały wrażenie sztywnych kończyn lalek, zanim udało im się wykonać jakiś ruch. Utracili zdolność trzymania się prosto. Kiedy, pochyleni ciagle do przodu, usiłowali ruszyć z miejsca, ich kroki stawały się coraz bardziej hektyczne, drobiące i przyspieszone w rozpaczliwych, bezowocnych próbach uniknięcia upadku na twarz, a i tak po chwili potykali się i padali na ziemię. Owo obce "ja" kierujące chorymi nie trzymało się żadnych reguł. Potrafiło wyrwać ich z paraliżującego letargu i wprawić w stan przerażającego bezustannego ruchu. Nie pozwalało im odpocząć, zatrzymać się w jednym miejscu, tylko - nie zważając na zużycie mięśni - gnało ich gdzieś w gorączkowym pośpiechu czy zmuszało do 
wykonywania gwałtownych działań. Działania te mogły przybierać formę kurczów lub wirowych ruchów. Potem chorzy wracali do stanu kataleptycznego bezruchu i bolesnego zwiotczenia - do czasu gdy pewnego dnia demony akinezy, zniszczenia wszelkiego ruchu, zwyciężyły i gasiły ostatnią iskrę życia.

[...] Ta choroba nie zna pokoju".

Pokoju? Chyba rozejmu. W ogóle niczego poza szturmem albo niczego poza skrytobójczym myleniem tropów. Ta choroba nie zna ani rozejmu, ani chwilowego zawieszenia broni, ani chwili ciszy przed salwą, ani odliczania kroków przed pojedynkiem. Nawet trudno mieć pretensje, w końcu choroba nie dżentelmen - nie umie się zachowywać. Ale jak się ten Parkinson zachowuje, to przechodzi wszelkie pojęcie. Swawolny Dyzio o instynkcie seryjnego mordercy? Coś to może mówi, wszystkiego nie, więcej mówi los pewnej ofiary, tym tragiczniejszy, że gość postanowił walczyć i w zasadzie nie poddał się do końca ${ }^{17}$.

Ten obszerny fragment pokazuje proporcje cytatu oraz odautorskiego dopowiedzenia i różnice tonacji między nimi. Po tym majowym wpisie następuje dłuższa przerwa w publikowaniu fragmentów Dziennika na łamach „Tygodnika Powszechnego”. Zapytany o to milczenie przez Dorotę Wodecka, Pilch wyznaje: „Jak piszę, to się boję, a jak nie piszę, to się boje jeszcze bardziej”"18. W wywiadach $z$ tego okresu głos Pilcha brzmi dramatycznie - choć autor próbuje unikać epatowania cierpieniem i niemoca, rezygnuje $z$ gawędziarskiego tonu na rzecz krótkich odpowiedzi.

Do dziennikowych zapisów wraca po dwóch miesiącach, nieustępliwy wobec oporu opowieści. Czemu służy ta rentgenowska szczerość? Identyfikacja $z$ samym sobą na kartach Dziennika wydaje się posunięta do granic niewyrażalnego - jakby Pilchowe credo: „literatura i życie to jedno i to samo”, miało się właśnie ucieleśnić. Pisanie nie polega tu - paradoksalnie - tylko na zawiazywaniu przymierza ze światem i z czytelnikiem. Bardziej staje się rozrywaniem tego węzła, próbą rozluźnienia połączenia między ,ja” autora a ,ja” narratora - bo tylko wtedy udaje się coś powiedzieć o sobie, kiedy z podmiotu uczyni się przedmiot opisu. Ratunkiem na niemoc zdaje się tylko to: pisanie i czytanie, uporczywe czytanie świata jako wielkiej księgi pełnej tajemniczych znaków, zagadywanie ludzkiej potrzeby zrozumienia rzeczywistości, zyskiwania pewności, która ma niwelować bezsilność w obliczu paradoksu. Pilch lubuje się w tropieniu paradoksów, chyba teraz to one (jak niegdyś kobiety) dodają mu wigoru. I dzięki temu zgoda na inercję artystyczną staje się nie źródłem porażki czy milczenia, ale zwycięstwem literackiego impetu; czymś na kształt instynktu życia. Paradoks - mawiał Émile Cioran w Zmierzchu myśli - sprawia, że „rozum zachowuje twarz wobec tego, co nieracjonalne” 19 .

Literatura jako remedium na kryzys? Tak, choć słowa nie zawsze pozwalają się udomowić i na pewien czas felietony Pilcha znikają z "Tygodnika Powszechnego”. Aby znów zagościć na łamach gazety, pisarz sięga po znany, oswojony i sprywatyzowany język, kreśli - jak sam ją nazywa - „autobiografię w sensie ścisłym”; znów niezawodnie będzie to literacki powrót do Wisły, do przeszłości. W Dzienniku drugim odnajdujemy te same miejsca, znajomą frazę, narrację rozpiętą między anegdotą a gawędą. Znika podział na daty, snuje się opowieść o początkach, podawana co tydzień $z$ przypomnieniem - zgodnie $z$ konwencja serialu - co było $w$ poprzednim odcinku. Opowieść udziela schronienia, miks pamięci i wyobraźni staje się przewodnikiem. Figurę zapętlenia narracji sugeruje nie tylko niemożność przekroczenia

19 É. M. Ci or a n, Zmierzch myśli. Przeł A. Dwulit. Warszawa 2004, s. 11. 
uładzonej, śpiewnej formy języka w taki sposób, aby to przekroczenie nie przywodziło na myśl bełkotu, ale oddawało bezsilność i pokore pisarza wobec nieuchronnego. Zapętlenie da się widzieć również jako rys charakterystyczny tego, co nazywamy codziennością. Uparte systematyczne zmuszanie się do pisania, cykliczne spacery, choćby tylko po gazetę do kiosku, wizyty u lekarza zaburzające rytm dnia - to także wypełnia dziennik. Literatura zrodzona $z$ codzienności ma jednak być czymś ponad nią, wyjściem $z$ tego, co rutynowe i znane, ma zaskakiwać. Dziennikowe kompendium składa się z narratorsko-autorskich reprezentacji, z wątków i sensów toczących ze sobą grę. Pilch nawet tam, gdzie przedstawia postaci, opisuje sceny i wydarzenia, relacjonuje lektury, zawsze jednocześnie opowiada o sobie człowieku snującym tę opowieść, podsuwa nam siebie i swój wewnętrzny świat, w którym gospodaruje sensami dającymi się odkryć. W ankiecie „Gazety Wyborczej" w roku 2013 przy okazji nominacji do nagrody Nike, poproszony o dokończenie zdania: „Chciałbym, żeby po przeczytaniu mojej książki czytelnik...”, Pilch dopowiedział: „wzbił się w przestworza” ${ }^{20}$.

Ciekawe życie jest zbiorem ciekawych opowieści. Wystarczy po jednej, wystarczy opowieść dzieciństwa, opowieść młodości, opowieść dojrzałości i fertig. Opowieść starości? ${ }^{21}$

Późna twórczość Pilcha to powrót do początków - autor ponownie zadaje sobie pytania: „kim jestem?” i ,jakim jestem pisarzem?” Na tym etapie życia zwrot do początku oznacza jednocześnie podsumowanie, przegląd spraw ważnych i znaczących, fascynacji i lektur, a także zestawienie doświadczeń. U Pilcha - od Dzienni$k a$ - proza czy, szerzej, pisanie stanowi synonim tego, co bliskie życiu. Choroba utrudnia pisanie, dlatego to właśnie ono - niczym zaklęcie - powstrzymuje zanik. W kilku wywiadach przy okazji wydania powieści Zuza albo czas oddalenia (2015) Pilch opowiada o chorobie i o powikłaniach po operacji, która przeszedł w kwietniu 2014. Sprawiły one, że przez rok nie mógł swobodnie mówić. Tematem powstałej w tym okresie książki jest zauroczenie starca młodą kobieta ${ }^{22}$. Pilch-czytelnik pamięta ten motyw z lektury Czesława Miłosza czy Thomasa Manna, znajduje go u Philipa Rotha, do którego ponownie sięga ${ }^{23}$. „Seks jako talizman wybawiający od śmierci, odwet śmiertelnego ciała na śmierci?" - pyta Marek Zaleski po lekturze Zuzy ${ }^{24}$. Tytułowy „czas oddalenia” sygnalizuje ton elegijny, jednak ironia równoważy nastrój, w zarodku tłumi patos. Pilch opowiada o takim dotknięciu przez czas, kiedy życie traci wcześniejszą oczywistość, przemijanie staje się w większym niż dotąd stopniu utratą, znaczoną bólem:

Choroby mnie w tamtym czasie wyniszczały bez pardonu. Parkinson szalał. Kręgosłup w rozsypce.

Dla kogo Nagroda Literacka „Nike” 2013? „Gazeta Wyborcza” 2013, nr z 6 VIII, s. 10.

J. Pilc h, Zuza albo czas oddalenia. Kraków 2015, s. 98.

Zob. J. S o b ol e w s ka, Księga dygotu. Rozmowa z Jerzym Pilchem o nowej książe, parkinsonie, pieniadzach i pokrewieństwach między pisarzem i prostytutka. „Polityka” 2015, nr 22.

Zob. ibidem, s. 72: „Miałem go za autora jednej książki, Kompleksu Portnoya, wydawało mi się, że tej młodzieńczej, szyderczej książce nic nie dorówna. Ale to nieprawda. Postanowiłem go w całości przeczytać. Często pojawia się u niego perspektywa starzejącego się pisarza, w powieści Duch wychodzi alter ego Rotha, pisarz po siedemdziesiątce, przeżywa fascynację młodą dziewczyną".

M. Zale s ki, Śmierć i dziewczyna. „Dwutygodnik.com”. Wyd. 160 (2015, nr 5). Na stronie: http:// www.dwutygodnik.com/artykul/5936-smierc-i-dziewczyna.html (data dostępu: 8 I 2019). 
Podniosłem telewizor, usłyszałem trzask zerwanej cięciwy - przeszło miesiąc bólu niepojętego. Odjęło mi mowę po operacji. Dygot wrócił w pełnej krasie ${ }^{25}$.

Narrator nie godzi się na to - podejmuje walkę o kolejną opowieść. Pilch wobec cierpienia szuka ratunku w literaturze, to ona porusza machiną egzystencji, daje okazję do przeżycia wszystkiego „raz jeszcze”. Ból wypowiedziany przestaje być jedynie osobisty. Jeszcze mocniej wybrzmiewa to w następnym utworze. 16 VIII 2015 na łamach „Tygodnika Powszechnego” rozpoczyna się publikacja fragmentów powstającej książki Historia dygotu. Tu o chorobie jest mowa wprost, to ona staje się motywem przewodnim opowieści, jej głównym przedmiotem:

Ze śmiertelną choroba - tak jest - nie wygrasz, ale bez urazy - powiem wam jedno: parkinson to kurwa - nie choroba. I nie tyle: „powiem”, co „powiedziałbym”. Gdybym był zdecydowanie młodszy i, co za tym idzie, bardziej bezceremonialny w doborze środków wyrazu, powiedziałbym jeszcze, iż choroba ta jest wulgarnie nierzetelna, wyłącznie kombinująca, jak by nieszczęsnego klienta oszwabić, obiecująca nie wiadomo jakie uciechy, a raczej dobrze, aż za dobrze wiadomo jakie. Powrót, całkowity powrót do zdrowia ta franca obiecuje, pierwszorzędny numer skądinąd, dławiąca perwersja, człowiek wie, że fiasko, że obiecanki-cacanki, ale oprzeć się ciężko ${ }^{26}$.

Choroba imitująca zdrowie bliska jest fikcji dającej złudzenie realności. Pilch opisuje powszedni dzień osoby zmagającej się z chorobą Parkinsona, widziany z perspektywy obcego spojrzenia - takiego, dla którego to, co znajome, pod wpływem strachu, wywołanego destrukcja, staje się obce, wprawia w zdziwienie, ale przede wszystkim paraliżuje. W tej chorobie świat zaczyna być pułapką - tak jak pułapką bywają słowa, gdy osuwają się w banał, kiedy próbuje się mówić o rzeczach najważniejszych. Przez zmianę tonacji opowieść przeistacza się w przejmującą historię niemożności poradzenia sobie z niezrozumiałym działaniem sił, na które nie ma się wpływu i których nie da się powstrzymać.

Chorować, mieć w sobie chorobę - nie znaczy znać się na niej. Niekiedy wręcz przeciwnie, niekiedy tak cię obezwładnia, że nie masz głowy do jej roztrząsania. Zwłaszcza, jak ukryta jest, jak jej źródła ukryte są gdzieś głęboko, np. w komórkach wzgórza. Albo programowo, natychmiastowo odwracasz głowę - nie chcesz jej znać, z zaciśniętymi zębami czekasz, aż się wyniesie. [...] Poczujesz jej obecność, gdy muśnie cię ostrze mdłości albo oślepi błyskawica bólu nieskończenie punktowego. Może usłyszysz jej szczurzy pisk, ale przecież nie ujrzysz jej nigdy. Zajrzeć w głąb mózgu to nie to samo, co zajrzeć w głąb gardła. Wszystkie choroby mogą zmieniać przebieg, uzłośliwiać się, mniej lub bardziej groźne brewerie wyprawiać - w przypadku choroby Parkinsona takie zmiany sa zasadą. Może ona zmieniać natężenie swych trucizn, może swe szkodliwości powściagać, może powtarzać w nieskończoność stare przypadłości, sięgać po nowe; dawać nadzieję - i zabijać ją w tej samej chwili. Oczywiście żadnych złudzeń. Żadnych zmył typu: zdrowiejemy. Żadnego: wieczór lepiej - rano przejdzie. Żadnych wahań. Obława rusza i powoli, bo powoli, ale czyni, co do niej należy ${ }^{27}$.

U Pilcha bój o słowa toczy się przeciwko bólowi i stracie, które sprawiają, że świat znika bezpowrotnie. Autor wiedział to już wcześniej, jego twórczość od początku problematyzowała swój status i była lekarstwem na obezwładniający lęk. Przed laty pisał:

Być może, literatura jest zaklinaniem widm, być może, pomiędzy zaklinaniem widm a wskrzesza-

Pilc h, Zuza albo czas oddalenia, s. 98-99.

J. Pil c h, Historia dygotu: Zastrzeżenia merytoryczne. „Tygodnik Powszechny” 2015, nr 33, s. 64. Ibidem. 
niem zmarłych granica jest niejasna, ale widma niech wystarczą. Trzeba przeganiać demony, ale trzeba im w pamięci dochowywać wierności. Pamięć jest substancją tego rzemiosła ${ }^{28}$.

W Dzienniku i Drugim dzienniku, a także w Zuzie czy też w Historii dygotu pisarz sprawdza żywotność własnej pamięci, ale - co ważniejsze - nie zajmuje się już kwestionowaniem albo umacnianiem pozycji literackiej; narrator przestaje uzasadniać swój byt. Późna proza Pilcha staje się ostentacyjnie literacka, a zarazem bezpardonowo odwołuje się do niemaskowanej realności intymnych doświadczeń. Jej narrator czerpie przyjemność $z$ istnienia słów, ich połączeń tworzących magię świata wykreowanego. W Historii dygotu widać, jak opowieść pozwala nie tyle rozpoznać siebie, ile rozeznać się w sobie i uzewnętrznić to, co blokuje, utrudnia, grozi atrofią. Poprzez opowieść dokonuje się eksterioryzacja choroby - w relacji między autorem, narratorem a czytelnikiem staje się ona przede wszystkim elementem materii literackiej. Chodzi więc o spojrzenie na siebie oczami innego, o pewne „wy-obcowanie” jako warunek konieczny pisania. Oddanie się władzy języka oznacza powołanie do życia świata przedstawionego, w którym także podmiot (ten $\mathrm{z}$ realnego świata) stanowi twór tekstowy.

Podobnie jest w książce Żywego ducha (2018), która opowiada o doświadczeniu swoistej zagłady, mianowicie o przebywaniu w świecie bez ludzi. Zostało ono przedstawione zarówno w wymiarze wewnętrznym, jak i zewnętrznym. Owa wymieszana perspektywa nie pozwala oddzielić tego przeżywania - doznanie wszechogarniającej pustki (samotność, brak kontaktu z otoczeniem, niemożność nawiązania relacji z tym, co na zewnątrz) determinuje postrzeganie rzeczywistości. W Pilchowej ironii, niczym w krzywym zwierciadle, przeglądają się rozpacz i lęk. Ukojenia szuka się w lekturze. Tym razem w Wydarzeniu Guida Morsellego znajduje Pilch klucz do własnej opowieści o kresie. Morselli pomaga mu odsłonić i wysłowić zmagania między końcem a trwaniem, między nadzieją a tym, co w jesieni życia określa się jako godzenie się $z$ losem, między bólem a ironią - przy czym żadnej $z$ tych paralel nie można w istocie rozumieć jako klasycznego przeciwstawienia. Sa to raczej nałożone na siebie warstwy chybotliwych stanów emocjonalnych. Mamy do czynienia, z jednej strony, z czymś fizycznie odczuwalnym, namacalnym, a z drugiej - z czymś wyobrażonym, rozgrywającym się między tym, co odautorskie, a tym, co przypisane jedynie narratorowi.

Budziłem się z trudem, zdawało mi się, że leżę na szpitalnym łóżku, nieziemsko zezowata pielęgniarka zmieniała mi kroplówkę. Bliski chyba najintensywniejszej w życiu ulgi, goraczkowo naciskałem na całkowite odzyskanie przytomności, niestety byłem w hotelu ${ }^{29}$.

Nadzieja przesyca u Pilcha katastrofizm niejako właśnie dlatego, że stoi za takim postrzeganiem dorobek literatury. Nawet jeśli historia świata jest opowieścią o totalnej destrukcji rzeczywistości, to owa narracja okazuje się sensotwórcza, bo ustanawia pewne ,ja”, które opowiada, oraz drugie ,ja”, które opowieść odczytuje. Obraz Statek szaleńców Hieronima Boscha da się interpretować jako metafora lęku, że zabraknie odbiorców nawiązujących relację z ,ja” pisarza. Być może, Pilch upewnia się, że nawet bez innych wciąż będzie to, co pozwala trwać - lektura. 
Twórczość dojrzała ma specyficzny stosunek do czasu. To literatura, w której mocniej akcentowana jest teraźniejszość jako efekt przeszłości, jako jej konsekwencja. Minione nie zostaje wprzęgnięte w melancholijny dyskurs, ale sprowadzone do widocznych znaków w teraźniejszości. Przyszłość z kolei nie ma już w sobie tego wielkiego potencjału oczekiwań, spełnień, nadziei i marzeń. „Ja” uwolnione od napięcia związanego z pamiętaniem, zakotwiczenie w „tu i teraz” likwidują przymus kurczowego przywiązania do faktów; autor nie musi czynić zastrzeżeń, w jakim stopniu fabuła czerpie $z$ jego biografii. Pisanie staje się wówczas realizacja pasji istnienia, przebywania pomiędzy słowami. To literatura o poczuciu bycia żywym, nie o odchodzeniu.

Nie wystarczy przy tym powiedzieć, że prozę Pilcha cechuje kultywowanie literackości, rozumianej zarówno jako wykorzystywanie wątków autotematycznych, jak i jako nadanie priorytetu konstrukcji, dbałości o formę. Pilch jest pisarzem w najbardziej potocznym sensie - pisanie to jego codzienność, praca, do której on zasiada: kiedyś każdego dnia, teraz: kiedy choroba mu ją umożliwia. Swoją osobność autor Historii dygotu zaznacza w stylu, ironii, ale i w podejściu do słowa pisanego chciałoby się rzec - totalnym. Interesuja go te teksty, które mają moc tworzenia wspólnoty z czytelnikiem. Przywoływanie pisarzy młodości i ponowna lektura ich książek to istotny motyw stanowiący ramę kompozycyjną obu tomów dziennikowych, nie mniej ważny w Historii dygotu.

Z czytaniem jest jak $\mathrm{z}$ kobietami - obcujesz z paroma naraz, kończysz $\mathrm{w}$ towarzystwie jednej. Niektórych w ogóle nie pamiętasz, inne mgliście. W każdym razie tych, które pamiętasz dokładnie, jest mało. Długo czekasz na tę, która zmieni twoje życie. Za młodu to się zdarza, potem nie ma co przesadzać. [...] Wracasz do ulubionych pozycji, do zapierających dech cytatów, do tego, co kiedyś ho ho. Niby w porządku, ale tylko w porządku. Niby OK, ale tylko OK. Nie ma co wracać do dawnych zachwytów, lepiej zostawić je w dawnej eksplozywnej formie.

Epoka arcydzieł też minęła. Były niezwykłe, są OK. Nowe? Podobno raz po raz się pojawiają. Nowe, ale nie moje. Już nie moje, niestety. Niestety z kurtuazji. Moje były w każdym szczególe arcydzielniejsze ${ }^{30}$.

W młodości emocjonalny odbiór świata i lektur jest prymarny, nie do zatrzymania; dawki fascynacji nie podlegają kontroli, instynkt życia popycha autora-czytelnika do zaspokojenia żądzy ,jeszcze więcej”. W twórczości dojrzałej - i w takiejże recepcji otaczającej rzeczywistości oraz dzieł literackich - kluczowa okazuje się nie afektywna pazerność, ale indywidualna świadomość, obcująca $z$ innymi i ze sobą za pomocą sztuki, za pomoca świata wykreowanego w słowach.

Zawołanie Pilcha: „Gombrowicz - wielki nauczyciel”, powtarza jego „kolega po fachu”, Zbigniew Mentzel. Trudno nie zauważyć, jak silnie pobrzmiewa u niego Gombrowiczowska lekcja wstrętu do wszelkiej ideologii, znajdująca odzwierciedlenie w wiecznej ucieczce od Formy. Owa ucieczka przyjęła u twórców takich, jak Mentzel czy Pilch postać niechęci, niewystarczalności, niemożności dokonania syntezy. Ale o wiele istotniejsze było to, że Witold Gombrowicz uprawomocniał ich poczucie wy- 
obcowania; dla autorów urodzonych pomiędzy rokiem 1950 a 1960, wychowanych na jego prozie, stanowił uosobienie wolności twórczej, potwierdzenie, że losem współczesnego pisarza stało się „życie pomiędzy” - pomiędzy systemem a prywatnościa - i „życie wewnątrz” siebie oraz wybranych opowieści. Nie da się jednak na Gombrowiczu zbudować nowej tożsamości - stwierdza słusznie Agata Bielik-Robson, wskazując na jego reaktywnośćc ${ }^{31}$. Gombrowicz nie wystarczał, gdy w 1989 roku wolność przestała być brakiem, a zmieniła się w coś banalnie dostępnego, i gdy rzeczywistość PRL-u, dotąd odrzucana, okazała się punktem odniesienia dla pojedynczego ,ja” jako jego prywatna przeszłość. Zarówno Pilchowi, jak i Mentzlowi gombrowiczowski śmiech nie wystarcza, bo nie oddaje polskiej specyfiki ogladanej od wewnatrz. W końcu nie o wygnańcach $\mathrm{z}$ ojczyzny mowa w ich utworach, lecz o ludziach pogubionych, żyjących wewnątrz świata rozpadającego się albo takiego, który właśnie się rozpadł. Śmiech staje się ratunkiem, ale i gestem rozpaczy. Pilcha, Mentzla czy Stasiuka różni od autora Ferdydurke także podejście do języka - u Gombrowicza stanowi on formę przemocy ${ }^{32}$, po którą sięga się, by dotrzeć do jądra tego, co pozbawione wszelkiej maski, ornamentu. Dla nich zaś język jest zbawienny, pomocny, pozwala dobrać się do przeszłości, opowiedzieć ją na nowo albo dopiero nazwać. Zatem wychowany na Gombrowiczu pisarz powraca i nazywa, by włączyć minione w „tu i teraz”, by odnaleźć tę siłę, która decyduje o życiu, o trwaniu i o pasji. Jeśli autor Trans-Atlantyku był nauczycielem podejścia do polskości, to teraz polskość w literaturze zdaje się istnieć właśnie dzięki jego uczniom, którzy dochodzą do niej własnymi ścieżkami $z$ wymuszonych bądź faktycznych peryferii.

W ostatnich latach Anderman i Mentzel - w zasadzie już nie piszą powieści, bywają felietonistami i kultywują działalność swoich literackich mentorów. W latach siedemdziesiątych i osiemdziesiątych obaj chętnie byli w kontrze, wtedy gdy warunki życia w PRL-u doskwierały, opowiadali się za prawdą, za niuansowaniem jej, tak by oddawała ona wiernie wszystkie odcienie rzeczywistości. W ich pisarstwie wyczuwa się od początku pewną ambiwalencję - wewnętrzne zmaganie się z odwiecznym pytaniem o to, kim jest twórca i jaka jest natura sztuki. Czy literatura ma realny wpływ na rzeczywistość i jaki on jest.

W przedmowie do Choroby więziennej Tadeusz Konwicki przedstawia Andermana jako „sceptycznego, krytycznego, chłodnego polskiego inteligenta wyposażonego w czterdzieści cztery pary oczu"33. Autor Sennika wspótczesnego to dla Andermana symbol sztuki, która nie tylko mówi o świecie, ale bierze za niego odpowiedzialność. „Moje pokolenie miało lęk przed pozą” - powiada Konwicki ${ }^{34}$. Dlatego przymusem stały się dla niego poszukiwanie autentyczności oraz stawianie pytań zamiast diagnoz. „Pisanie było dla mnie aktem spontanicznym. [...] Pisałem z jakiejś potrzeby" - wyznaje on Andermanowi w filmie Co ja tu robię? Tadeusz Konwicki ${ }^{35}$.

Koniec polskiej cywilizacji. Z A. Bi elik-Rob s on rozmawia A. Pu chejda. „Znak” 2011, nr 4, s. 31.

Zob. A. Kij ow s ki, Granice literatury. Wybór szkiców krytycznych i historycznych. Zebrał, oprac., wstęp T. Burek. Warszawa 1991, s. 266.

33 T. Ko n wi cki, przedmowa w: J. An de r m a n, Choroba więzienna. Scenariusz filmowy. Warszawa 1991, s. 6.

Co ja tu robię? Tadeusz Konwicki. Reż. J. An d e r m a n. TVP 2009.

Ibidem. 
Anderman, przez lata marzący o zawodzie reżysera (był nawet jakiś czas asystentem Konwickiego na planie filmowym), ostatecznie nim nie został; po latach jednak zrealizował tę pasję i wyreżyserował dokument poświęcony właśnie swemu literackiemu mistrzowi. Film rozpoczyna się od rozmowy pisarzy w parku, Konwicki opowiada Andermanowi o Wilnie, które go ukształtowało, o partyzantce, o publikowaniu w drugim obiegu w latach siedemdziesiatych jako akcie bycia etycznym. „A czy te nasze ostatnie lata, czy to nie wymaga lojalności z tym naszym biednym skołatanym społeczeństwem? Dlaczego pan przestał pisać?" - pyta Konwickiego Anderman i zaraz uzyskuje żywiołową odpowiedź: „Bo jesteśmy wolni! Nie czuję się odpowiedzialny. Musi pan sobie zdawać sprawę, że ja dręczyłem się odpowiedzialnością za PRL, w który się włączyłem”. Z lektury powieści Konwickiego wyniósł Anderman etykę, która leży u podstaw jego sposobu myślenia o świecie. W latach siedemdziesiątych i osiemdziesiąych nakazywała mu ona być przede wszystkim demaskatorem rzeczywistości, jej absurdów, skrętów ideologicznych i manipulacyjnych. Tym od początku charakteryzuje się jego pisarstwo. W świecie wyłaniającym się z kart prozy Andermana właściwie nie ma nadziei, a tym, co ocala jej resztkę, jest empatia. Znane ze strzępów wypowiedzi, uchwyconych w magnetofonowym zapisie, bezimienne postaci, które występowały w pierwszych opowieściach Andermana, budziły niepokój czytelnika nie tylko dlatego, że stanowiły wyłom w zabetonowanej rzeczywistości PRL-u. Wydawały się sygnałem istnienia innego świata - marzeniem o wspólnocie jednostek. Uważny narrator $z$ Zabawy $w$ głuchy telefon, Gry na zwłokę czy Braku tchu przypominał archiwistę, próbującego ocalić świadomość posługującą się językiem nieskażonym frazesem. Krytyk „Twórczości” Henryk Bereza, który patronował Andermanowi i innym pisarzom „rewolucji artystycznej”, przez lata jako wierny czytelnik młodych prozaików tropił w ich tekstach ślady języków, które nazywał pierwszymi albo pierwotnymi. Nie włączając się w dawny spór o zasadność postulatów i rozpoznań Berezy, wypada w tym miejscu jedynie dopowiedzieć, że jeśli u Andermana pojawia się to, co ja określam jako język nieskażony, to można o tym myśleć jako o ,języku pierwotnym” tylko w znaczeniu „podstawowym” - budującym świat wartości zasadniczych.

Wybitna umiejętność obserwacji rzeczywistości i celność opisu-kopii robią w prozie Andermana najmocniejsze wrażenie. Dowodem na to mogą być opowiadania $z$ tomu Kraj świata (1988) czy wreszcie z powstającego przez wiele lat 3-częściowego cyklu Fotografie ${ }^{36}$ - kadr staje się podstawowa formą dla Andermana, marzącego niegdyś o karierze filmowca. W kadrze pamięci utrwalone zostają momenty z życia świata, który - trudno oprzeć się wrażeniu - znika na oczach czytelnika. Owo znikanie najwyraźniej widać w tych fragmentach cyklu, które dotyczą osób bliskich autorowi lub tylko ledwo znanych czy przypadkowo spotkanych. Tu pobrzmiewa ton czułości - bliski postawie empatii wobec lumpów i bezdomnych, włóczących się i pogubionych z pierwszych utworów Andermana. Tam właśnie jego ,ja” bezustannie badało siebie i ciagle siebie podważało, dlatego nie miało szans, by ukonstytuować się $\mathrm{w}$ pełni. Bohater jednego $\mathrm{z}$ ostatnich utworów, To wszystko, ma imię, po raz pierwszy jest podmiotem opowieści, ale bynajmniej nie dlatego, że zyskał podmio- 
towość. Zabieg nazwania postaci służy unaocznieniu, jak w „byciu kimś” utożsamia się „widzialność” z zaledwie „rozpoznawalnością”, zapewniająca miejsce w rzeczywistości medialnej. Współczesny żywioł celebryctwa nie oznacza posiadania sensu czy zdolności generowania go. Anderman trafnie portretuje, zreformowanego po 1989 roku, polskiego cwaniaka, kanciarza, karierowicza, ale teraz brakuje w owej prozie tej zagubionej postaci, której pisarz niegdyś udzielał głosu, dosłownie odtwarzając zasłyszany na ulicy dialog; nie ma ani bohatera, który tak usilnie szukał domu, ani narratora, który byłby nosicielem nadziei, a nie jedynie demaskatorem. I wydaje się, że właśnie ów niedostatek empatii w zbudowaniu wyrazistego narratora, którego pogubienie można by poczuć, decyduje o tym, że najnowsze powieści Andermana sa już pozbawione dawnej siły oddziaływania.

Adam Zagajewski tak komentował rzeczywistość, w której króluje śmierć, wyłaniająca się z prozy W. G. Sebalda:

Pisarz wobec świata, w którym żyje, musi - powinien - może - niech próbuje - przeciwstawić sobie to, co jest, i to, co mogłoby być, co jest być może marzeniem tylko, tylko nadzieją ${ }^{37}$.

U Andermana świat stanowi albo archiwum pamiątek po tych, co odeszli, albo uniwersum bez nadziei, w którym empatia jest niemożliwa. To świat nie umiejący przekroczyć własnej dekadencji. I tu znów ambiwalencja - wydaje się przecież, że Anderman dekadentem nie jest, że potrafi być czułym portrecistą epok oraz ludzi, nawet odległych od niego pod względem światopoglądu, czego dowodem jest choćby jego esej poświęcony autobiografii Pióro Marka Nowakowskiego, pisarza, który jak Anderman celnie zauważa - kierował się w życiu zasadą osobności:

Odszedł [...] w niebyt dawny świat Nowakowskiego - peryferyjne dzielnice, bazary, słynne knajpy, speluny i meliny. Nie ma ferajny, która ten świat zaludniała: złodziei, kombinatorów, dziwek, meneli, oszustów. Jest wrogi, słabo przyswajalny przez autora po 1989 r. światek, który go odpycha i [który] on sam ocenia w sposób - jak się wydaje - znacznie uproszczony ${ }^{38}$.

Bo właśnie na tym polega zadanie pisarza: opowiedzieć o świecie, który odchodzi albo jest skazany na wymarcie, ale opowiedzieć tak, by pokazać odcienie szarości zamiast czarno-białej perspektywy. Anderman dobrze to wie, gdyż sam hołduje takiemu modelowi opowieści: czujnej i ostrej, podejrzliwej i pełnej zrozumienia jednocześnie. Tam, gdzie Anderman jest empatyczny (jak w Kraju świata, najbardziej zaś w cyklu Fotografie), tam zwycięża, proza jego emanuje nieodpartą prawdą; tam natomiast, gdzie stara się pełnić funkcję diagnosty rzeczywistości, bezwzględnego prokuratora, a nie obrońcy, któremu przyświeca idea prawdy artystycznej (jak dzieje się to w Chorobie więziennej czy w ostatnich książkach) - tam jego twórczość przegrywa, widać brak wyrazistego bohatera oraz postaci reprezentujących nas, czytelników; sposób przedstawiania świata zaś trąci dydaktyzmem.

I, paradoksalnie, $w$ tej literaturze, $\mathrm{z}$ taką mocą mierzącej się $\mathrm{z}$ własną konwencjonalnością, to empatia ocala przed zagładą świat prozy Andermana. Empatia, której nie można traktować jako synonimu rozumienia ${ }^{39}$, kieruje czytelników jed-

A. Za gajews ki, Melancholijny i konkretny. „Zeszyty Literackie” 2012, nr 2, s. 40.

J. An d e rm a n, Tren Marka Nowakowskiego. „Gazeta Wyborcza” 2012, nr z 30 VI - 1 VII, s. 33.

Zob. A. Klu b a, Litość bez trwogi-zagadnienia empatii i dystansu w literaturze. W zb.: Literackie reprezentacje doświadczenia. Red. W. Bole cki, E. Naw r o cka. Warszawa 2007. Kl u ba tak 
nak ku hermeneutyce, a ta próbuje nas pogodzić ze światem, odzyskać utracony porządek znaczeń.

Jeśli przyjać, że empatia zakłada chwilowe zawieszenie własnych wyobrażeń i sądów po to, aby otworzyć się na świat kogoś drugiego, to autorskiego odpowiednika postawy empatycznej dopatrywać się można od biedy w tym, co Ważyk nazywał „zasadą dośrodkową”. Była ona w jego opinii zerwaniem z ekspresjonistycznym dążeniem do eksterioryzacji wnętrza na rzecz dotarcia do tego, co najostrożniej ująć można jako „nie-ja”. U Ważyka jednak owo „nie-ja” oznacza po prostu, jak pisze, „rzeczywistość” [.... ${ }^{40}$.

Tam, gdzie jest empatia - tam Anderman nie boi się melancholii. Ale w jego prozie znacznie częściej świat rozpada się i nikt go nie sankcjonuje - nie ma bohatera reprezentującego rzeczywistość w jej złożoności. Podobnie jak uczucia torują u Andermana drogę do archiwum pamięci, które otwiera się w trakcie pisania, tak empatia sprawia, że przekaz literacki nie zamyka się w formie oczekiwanego z góry komunikatu, a porozumienie $z$ czytelnikiem staje się dzięki niej znacznie silniejsze.

$Z$ pisarzem uparcie zwiazanym $z$ jednym autorem mamy do czynienia $w$ przypadku Mentzla. Do wywiadu-rzeki namawiał on swego mistrza, Leszka Kołakowskiego, przez 18 lat. Zapis tej rozmowy, zawarty w 2-tomowej publikacji Czas ciekawy, czas niespokojny, podsumowany jest na końcu stwierdzeniem 80-letniego filozofa: „A wszystkiemu winien Zbigniew Mentzel”, wskazującym na bardzo ważną rolę eseisty i pisarza, zafascynowanego dziełem Kołakowskiego ${ }^{41}$. $Z$ pytań zadawanych przez Mentzla dowiadujemy się, jak drobiazgowo zna on poglądy, wypowiedzi, wykłady, książki i życiorys filozofa, jak sprawnie porusza się w tym oceanie informacji. Szczególny stosunek Mentzla do dzieciństwa słychać też w takich pytaniach jak np.: „Pierwsza przeczytana książka?”, „Lubiłeś baśnie? Na przykład baśnie braci Grimm?”, „Miałeś w dzieciństwie ulubiony mit grecki?”, „A bywałeś przed wojną w Warszawie?" 42

Książkę Czas ciekawy, czas niespokojny zwykło się określać jako mówioną autobiografię i światopoglądowy autoportret filozofa. Taki jej kształt jest również zasługą Mentzla. Bez tego rodzaju rozmowy, która wymaga od pytającego uporu, nie byłoby tej książki. Wprawdzie Kołakowski zastrzega tylko dwa tematy tabu („Nie będziemy rozmawiać o moich Rodzicach. Jestem bardzo przywiązany do bliskich Zmarłych. [...] Nie chcę rozmawiać o tym, kto z kim spał") ${ }^{43}$, ale niechętnie wypowiada się o swojej twórczości, choć o przeszłości mówi rzetelnie i szczerze, nie wybielając się i nie interpretując faktów. Mentzla ciekawią wybory światopoglądowe Kołakowskiego - polityczne oraz ideowe. I w tym gąszczu pytań raz na jakiś czas pojawia się coś, co Kołakowskiego rozpędza do opowieści własnej, nie tej wyznaczonej szlakiem myśli pytającego. Bohater książki wygłasza minieseje na przeróżne

pisze o hermeneutyce F. Schleiermachera: „definiował [Schleiermacher] jeszcze postawę hermeneutyczną jako zdolność unikania niezrozumienia, jako chęć odsłonięcia tajemnicy świata wewnętrznego drugiej osoby. Jego hermeneutyka była jeszcze hermeneutyką wczuwania się w innego, a nie strategia podejrzeń przyjmowanych wobec czyjegoś tekstu...” (ibidem, s. 84-85). Ibidem, s. 87. Słowa „zasada dośrodkowa” pochodzą z książki A. W a ży k a Dziwna historia awangardy (Warszawa 1976, s. 17).

41 Czas ciekawy, czas niespokojny. Z L. Kołakowskim rozmawia Z. Mentzel. Cz. 2. Kraków 2008. Zob. też cz. 1 (2007).

42 Ibidem, cz. 1, s. 25, 26, 27.

43 Ibidem, s. 16. 
tematy: o miastach, o pejzażach, o stanowiskach filozoficznych oraz o pojedynczych ludziach, o sposobach kłamania u Chińczyków i u Japończyków. Te dygresje własne Kołakowskiego przerywaja tok rozmowy tylko pozornie, bo odbywa się ona wówczas już na innym poziomie - dwóch indywidualności słuchaczy.

Intrygująca Mentzla sprawa stosunku Kołakowskiego do religii, powracająca wielokrotnie w wywiadzie, znalazła zaskakujace podsumowanie już po śmierci filozofa. Jesienią 2010 wydawnictwo „Znak” opublikowało odnalezione wykłady Kołakowskiego o herezji, które wygłaszał on pomiędzy listopadem 1982 a lutym 1983 w Radiu Wolna Europa. Ich „odnalezienie” (wykorzystane przez oficynę jako marketingowy zabieg) to także zasługa Mentzla, któremu filozof na pół roku przed swym odejściem powiedział o istnieniu wersji tekstowej i dał egzemplarz ${ }^{44}$. W zamieszczonym w internecie jesienią 2010 nagraniu promujacym ów zbiór Mentzel zabiera głos, nie tylko wprowadzając czytelnika w myśl Kołakowskiego, lecz wykorzystując ową myśl jako komentarz do sytuacji społeczno-politycznej roku 2010, kilka miesięcy po katastrofie smoleńskiej:

Kiedy Leszek Kołakowski wygłaszał swoje wykłady na temat herezji, był to rok - zima roku 1982, a więc pierwsza rocznica wprowadzeniu stanu wojennego. Była to sytuacja taka wojenna, lud nazywał tę wojnę - „wojną polsko-jaruzelską". W Warszawie na Krakowskim Przedmieściu krążyły milicyjne radiowozy, ludzie układali krzyże z kwiatów, jeździły armatki wodne, ludzi pałowano i puszczano gaz łzawiący. I oto paradoks historii sprawił, że teraz, kiedy książka o herezjach się ukazuje, także mamy w Polsce do czynienia z pewną wojną, potocznie nazywana „wojną polsko-polską”, z konfliktem politycznym, $z$ konfliktem partyjnym. I znowu jest tak, że kiedy w Warszawie wychodzimy na Krakowskie Przedmieście, ludzie noszą krzyże, układają krzyże, straż miejska puszcza czasami gaz pieprzowy. Jest ogromne zamieszanie. Co się dzieje? Czy tutaj teraz też możemy mówić o heretykach, o herezjach? No, niezupełnie jest tak, bo kiedyś wielkie herezje, wielkie herezje w łonie Kościoła, dzieliły ludzi i ludzie się spierali, ale o sprawy - wydawałoby się - cokolwiek ważniejsze. O to, czy będziemy zbawieni, czy będziemy potępieni, czy: jak rozumieć pojęcie Trójcy Świętej? Czy jest łaska nieodparta? Czy mamy wierzyć, czy nie wierzyć w niepokalane poczęcie najświętszej Marii Panny? Były to pewne zagadnienia dogmatyczne i ludzie brali to bardzo serio.

No, teraz w tym całym zamieszaniu, które przeżywamy w kraju, ludzie nie spierają się o takie sprawy. Spierają się o sprawy ściśle polityczne, dotyczące władzy, tego, kto powinien mieć władzę. Ale jest coś, co jest podobne do tamtych czasów, to znaczy są ludzie, sa grupy ludzi, sa pewne ciała partyjne, ideologiczne, którym się wydaje, że mają monopol na prawdę. A to jest istota rzeczy. Ponieważ żeby była herezja, musi być ortodoksja, a więc ścisła wierność jakiejś absolutnej prawdzie, jakimś dogmatom. I Leszek Kołakowski właściwie przez całe swoje życie przeciwstawiał się ludziom czy grupom ludzi, którym się wydawało, że mają monopol na prawdę. I w tej książce właśnie dopomina się o taki sceptyczny hamulec wobec pewności. Wobec pewności absolutnej. I myślę, że może dlatego Leszek Kołakowski ciagle budzi zainteresowanie, że nie jest kimś zdefiniowanym, kimś, kto ma swoją wyraźną, czytelną doktrynę. Ale jest takim strażnikiem sceptycyzmu i kimś, kto podważa samozadowolenie i spokój, który płynie z takiego komfortowego poczucia, że ma się monopol na prawdę ${ }^{45}$.

Dopiero w formie tekstu drukowanego ten obszerny fragment wystapienia Mentzla pokazuje się dobitnie jako swoiste wyznanie wiary w sceptycyzm i samokrytycyzm, w pokorę, która pomaga nie zgubić się w czymś, co nazwać by można wzniośle walką o niezafałszowany obraz świata.

Zob. Zbigniew Mentzel o „Herezji” Leszka Kołakowskiego (1). Na stronie: https://www.youtube. com/watch?v=IjN4iTJOhcw (data dostępu: 7 I 2019).

45 Zbigniew Mentzel o „Herezji” Leszka Kołakowskiego (2). Na stronie: https://www.youtube.com/ watch?v=b9vEq0bkahc (data dostępu: 7 I 2019). 
Problem sztuki, jej powinności wraca u Mentzla wielokrotnie. Temu poświęcone były jego zapiski Pod kreska, dokumentujące zmierzch PRL-u. Sztuka i literatura pojawiają się także w zbiorze Niebezpieczne narzędzie $w$ ustach, zawierającym teksty z lat 1997-2001, przeważnie publikowane wcześniej w „Tygodniku Powszechnym”. Mentzlowi bliski jest pogląd, że sztuka ma moc sacrum, że współcześnie to ona może odegrać rolę przewodnika. Taki ton pobrzmiewa, gdy eseista analizuje list papieża do artystów, mówiący o potrzebie nowego przymierza sztuki i religii:

Jan Paweł II daje wyraz przekonaniu, że sztuka autentyczna - kluczowe to pojęcie pojawia się $\mathrm{w}$ liście wielokrotnie - w samej swej istocie bliska jest doświadczeniu religijnemu, nawet jeśli od religii się odwraca, sztuka zaś nieautentyczna nawet wtedy, kiedy doświadczenie religijne jest jej treścia jedyną, pozostaje $\mathrm{z}$ istotą religii w głębokiej sprzeczności.

$[\ldots]$

List Papieża do artystów nasuwa pytanie, czy umiemy dziś odróżniać sztukę autentyczną od nieautentycznej, od sztuki „sztucznej” - słowem, od pseudosztuki w niezliczonych jej odmianach, zarówno więc tej tworzonej przez ludzi pozbawionych elementarnych sprawności, dzięki którym człowiek może być artystą, jak i tej, która nie jest koniecznością duszy i poszukiwaniem Tajemnicy, tylko udawaniem, poza, grymasem, grą ${ }^{46}$.

Autor Niebezpiecznego narzędzia $w$ ustach należy od lat do tropicieli tego, jak język w czasach PRL-u potrafił zafałszowywać rzeczywistość. W swych felietonach Mentzel pokazuje się też jako wielbiciel wielkich pisarzy (Miłosza, Różewicza, Pilcha), bibliofil i czytelnik lektur nieoczywistych, jak np.: Scyzoryki. Historia, marki, modele, producenci Bernarda Levine’a, Stownik towaroznawczy artykułów żywnościowych Michała Ziemiańskiego, Mosty na Wiśle i ich budowniczowie Bolesława Chwaścińskiego. Literatura, której hołduje Mentzel - poza tym, że porządkuje ona rzeczywistość, poszerza wiedzę i skłania do przemyśleń - ma posmak dziecięcej przygody, odkrywanej tajemnicy, jest niczym odnalezione gdzieś na strychu pamiętniki prababki. Mentzel okazuje się też takim czytelnikiem - poszukiwaczem przygód i tajemnicy - gdy opisuje to, co sam czyta po wielokroć, zachłannie i z zachwytem; gdy np. zwierza się z trzykrotnej (a i tak, jego zdaniem, nie wystarczajacej) lektury powieści Tysiąc spokojnych miast Pilcha:

W pełen znaków Opatrzności wigilijny wieczór Jerzyk pozostaje dzieckiem, ale jest też już dorosły: po raz pierwszy, w zastępstwie [zmarłego] ojca, przyprowadzić ma do domu pana Trąbę, który, jak co roku, spóźnia się na wieczerzę.

Przyprowadza go. Wchodzą po schodach. Otrzepują ośnieżone buty. W zamku obraca się klucz. OJCIEC OTWIERAE NAM DRZWI - czytamy na koniec i w tym prostym zdaniu, które jak lakowa pieczęć Naczelnika Poczty zamyka narrację, jest dziecięca ufność, moc zaklęcia, potęga mitu i Bóg wie, co jeszcze... ${ }^{47}$

Stasiuk powraca w dawne miejsca, wraca tam w opowieściach, powtarza to samo, jakby bał się, że straci nieodwracalnie opowieść, jakby wierzył (i faktycznie chyba wierzy), że trwanie, pamiętanie możliwe jest tylko w niej. W mitologii Stasiuka, osadzonej na peryferiach, ogląda się rzeczywistość w zachodzie lub we wschodzie 
słońca, w spowolnieniu. Melancholia Stasiuka, która doczekała się skatalogowania i opracowania naukowego ${ }^{48}$, nie zmierza ani do śmierci, ani do nicości, nie jest podszyta depresją. Autor Dukli przezwycięża smętne poczucie wyczerpania za sprawą metaforyki, wydobywa malarską moc języka, jego subtelność wzniosłości i wzruszenia, będącego - obok powagi - jednym $\mathrm{z}$ największych tabu we współczesnej sztuce. U Stasiuka odsłania się ono za pomocą słów i nie razi dzięki urzekającej metaforze. A ocalająca metaforyka języka pozwala zadomowić się w każdej przestrzeni. Stasiuk pisze:

Przestrzeń jest dla mnie strasznie ważna. Jako kategoria religijna niemalże. Pobyt w Mongolii był dla mnie doświadczeniem mistycznym. Kiedy widzisz, że przed tobą jest 100 kilometrów pustki, ale tak pięknej, że nie widziałeś czegoś porównywalnego, to masz dotknięcie wymiaru, który cię przerasta kompletnie. Religijnie czy pozareligijnie, ale też fizycznie i zmysłowo. Było gorąco i sucho, miałem ochotę całkiem się rozebrać i wejść w to. Ocierać się. Iść przez step i czuć rozkosz ${ }^{49}$.

Ów zindywidualizowany i podszyty doznaniami język występuje przeciw postawie konsumpcjonizmu turystycznego, w prozie Stasiuka opanowuje lęk, pozwala zbliżyć się do tajemnicy, którą pisarz tropi w rzeczywistości, w jej prześwitach, w odpadach, w biografiach rzeczy i krajów. Język ułatwia także z ogromu doznań, tego, czego się doświadcza, wypreparowanie pasji, która pcha do życia, do tworzenia, a nie rozleniwia w smutku. Ta potrzeba słów wreszcie zmusza do podjęcia kolejnej wyprawy, po to by pobudzić wyobraźnię i pamięć. Spowolnienie właściwe melancholikowi wydaje się u Stasiuka formą innej podróży, czymś na kształt gestu kierowcy spoglądającego w lusterko wsteczne; jest momentem scalającym realność przeżycia ze świadomością języka, wrażenie $\mathrm{z}$ nazwaniem, bycie $\mathrm{z}$ opowieścią o byciu. Autor porównuje podróżowanie do literatury:

Pisanie jest wymienianiem nazw. Tak samo jest z podróżą, gdy koraliki geografii nawlekają się na nitkę życia. Ani z lektury, ani z drogi nie wracamy wiele mądrzejsi. Granice jak rozdziały; kraje jak gatunki literackie, epika tras, liryka odpoczynków, czerń asfaltu nocą w światłach auta przywodzą na myśl monotonną i hipnotyczną linię druku, która przecina rzeczywistość, wiodąc nas wprost do urojonego celu. Nie ma nic na końcu książki, a każda przyzwoita podróż zawsze przypomina mniej lub bardziej poplataną pętlę ${ }^{50}$.

Melancholia Stasiuka to nie nostalgia za dawnym światem ani próba ożywienia PRL-u; nie służy do obrachunków z własną biografią. Jest narzędziem przeznaczonym do pokazania skrajnie podmiotowego świata, w którym uwaga patrzącego usiłuje zedrzeć maskę języka i dobrać się do rzeczywistości. Melancholia staje się więc próbą przełamania nierealności między jednostką a jej doświadczeniem. Stąd bierze się moc słów, bo tylko to, co nazwane, zyskuje materialność, najmocniej widoczną w opisach, wydobywających z języka magię metafory. U Stasiuka już pejzaż dzieciństwa zamknięty jest w krajobrazie - zawsze intensywnym, najczęściej zimowym:

Zob. A. Ma da li ń s ki, Nicość, pamięć, wyobraźnia. O melancholii Andrzeja Stasiuka. Praca doktorska napisana pod kierunkiem prof. D. Nowackiego. Katowice 2013. Na stronie: http://www. sbc.org.pl/dlibra/doccontent?id=88100\&from=PIONIER\%20DLF (data dostępu: 17 I 2019). A. St a si u k, Załamanie światta. Rozmawiał A. F r a n a s z e k. „Miłosz jak świat - rodzinna Europa”. Dodatek do „Tygodnika Powszechnego” 2011, nr 52, s. 6.

50 A. Stasiuk, Dziennik okrętowy. W: J. Andruchowycz, A. Stasiuk, Moja Europa. Dwa eseje o Europie zwanej Środkowa. Wyd. 3. Wołowiec 2007, s. 111. 
Za tydzień zaczyna się Boże Narodzenie. Lampy świecą ciepłym, żółtym blaskiem i jest mi dobrze. Kusi mnie jednak chłodny błękit za oknem i samotna droga do domu wśród ośnieżonych czarnych drzew i zapalających się latarni. To jest moje najwyraźniejsze, najżywsze wspomnienie $z$ dzieciństwa. Towarzyszy mi aura dziwnego smutku i jednocześnie najgłębszej radości. [...] Po prostu pierwszy raz w życiu poczułem jednocześnie pragnienia bycia „tu” i bycia „gdzie indziej” 51 .

W Stasiukowych opisach przestrzeni pobrzmiewa echo romantyczne: ten sam aktywny stosunek do natury, podobna wiara w wyobraźnię, skupioną na sensualnym odbiorze świata, sięgającym poza realność. Zdaniem Mickiewicza, natura uobecniona w tekście była wielkim wkładem literatury polskiej w rozwój sztuki Europy:

Sztuka ucieka się do tysiącznych sposobów, aby obudzić w duszach ludzi Zachodu czucie cudowności. U nas dosyć na to samej przyrody. Ta dziewicza, wspaniała i dzika przyroda, która co dzień nowe roztacza świetności i nowe okropieństwa, ma dwojakie znamię świętości i wzniosłej grozy ${ }^{52}$.

Według poety krajobraz przenika zatem tajemna nuta transcendencji. Pobrzmiewa ona i u Stasiuka, jakby tylko wieczność natury dała się ocalić. W końcu współczesne melancholijne spojrzenie skupione jest na znikaniu: dawnego świata, wartości, którym hołdowali dziadkowie, czy - co najbardziej przerażające - pamięci. To pustoszenie - nieuchronne, o którym wiadomo, że nie da się go zatrzymać zmusza narratora do ocalania resztek, fragmentów, kruchych reprezentacji. Temu służy opowieść, repetycja; a jeśli nie da się skroić historii, to ratunkiem stanie się zapis wrażenia, notatka, komentarz, powtórna lektura, w której na nowo albo inaczej można sprawdzić, czy w dziedzictwie, rezerwuarze sensów, pozostaje jeszcze to, co pozwala się odnaleźć pisarzowi i czytelnikom. Melancholijne poczucie odchodzenia niezwykle mocno sprzężone jest obecnie ze sztuką - szczególnie ze sztuką słowa, która nie poddaje się wyczerpaniu i uporczywie tropi zachwyt, pasję, a utracone zamienia we wzruszenie. Taka melancholia zmusza do lektury kontemplacyjnej, w której następstwie wchodzimy w prywatny świat pisarza, szukając siebie i tak literatura (czy szerzej kultura) staje się miejscem wspólnym autora i czytelnika, czyniacc ich uczestnikami tego samego spotkania $z$ tekstem.

Niejednokrotnie mowa tu była o powrotach przeszłości albo o powrotach do niej - w przypadku utworów Stasiuka polegają one na ucieczce do tego, co znane i nazwane. W książce Jadac do Babadag pisarz przekonuje czytelnika, że nie z powrotami mamy do czynienia, ale ze stałym istnieniem przeszłości i z tym, jak owo istnienie jest intensywne. Wybór języka wydaje się o tyle ważny, że decyduje o tym, czy mówić będziemy wyłącznie o stracie, czy też akcent postawimy na ocalaniu ginącego świata. We współczesnym melancholijnym wrażeniu straty nie ma przeczucia ostatecznego końca, unicestwiającej katastrofy, czającej się nicości. W spowolnieniu, w którym można sobie uświadomić znikanie - niejako zadumać się nad nim - szuka się ocalenia. Stasiuk, będąc przeciwny kulturze pośpiechu i konsumpcji, zamyka się w prywatnej medytacji. Być może, nigdy tak silnie nie była ona związana $z$ imperatywem opowiadania, które utrwala te same frazy, snuje tę samą narrację, ocalająca od zapomnienia.

51 A. Stasiuk, Tekturowy samolot. Wyd. 2. Wołowiec 2001, s. 5.

52 A. Mickiew i z, Literatura słowiańska. Kurs czwarty. W: Dzieła. Wyd. Rocznicowe. T. 11. Oprac.

J. Maślanka. Przeł. L. Płoszewski. Warszawa 1998, s. 69. 
Pojawiająca się tu przy okazji romantyczna polifonia stanowi u przywoływanych przeze mnie pisarzy coś więcej niż tylko echo dawnych lub ponownych lektur czy nawiązanie do nich. Ta rozmowa $z$ tekstem podszyta bywa pragnieniem czegoś, co niedoskonale oddane zostaje przez słowo „emocjonalność”. Zawierają się w tym i siła pierwszego odczucia, i nieuchwytność wrażenia, i moc tajemnicy. To sposób opisywania, który zbliża do haptycznego doświadczania rzeczywistości. Romantycy - pisał przed laty Łempicki - patrza na świat jak na zabytek literacki, a ich podejście ma charakter hermeneutyki ${ }^{53}$. Czytanie świata i kultury przez pisarzy omawianych w niniejszym studium bliźniaczo przypomina lekturę romantyczną. Stasiuk literaturę, zarówno tę pisaną, jak i tę czytaną, traktuje jak talizman. Autor Białego kruka z podarowana przez Pilcha fotografią Płatonowa w kieszeni będzie przemierzał Chiny, chcąc zrozumieć, czym był komunizm, oraz zobaczyć to, co tak doskonale Płatonow ujął w powieści Wykop ${ }^{54}$. Dziśs spotkanie $z$ tekstem wyrasta chyba najbardziej z potrzeby rozpoznania siebie; i w pisaniu, i w czytaniu szuka się własnego odbicia, czegoś bliskiego duchowo lub intelektualnie. To ważna konstatacja, bo oznacza, że współcześnie literatura staje się miejscem, w którym autor i czytelnik spotykają się w pogoni za tym samym. I tym intensywniej literatura pociąga, im silniej daje o sobie znać jej tajemnicza moc, ukryta między słowami, moc nie do nazwania, jak u Płatonowa. Pilch powiada, że geniusz Płatonowa próbował (w Katastrofach w powietrzu) wyjaśnić Josif Brodski i wśród wielu jego uwag najcelniejsza wydaje się jedna: „Tych książek nie da się opisać”55. Ów fenomen niewytłumaczalności, niemożności uzasadnienia stoi za 40-letnią fascynacją Płatonowem u Pilcha, za którym i Stasiuk powtórzyłby: „Bez tajemnicy ani dudu” 56 .

\section{4}

Tajemnica uwodzi także Stefana Chwina, który z czasem z pisarza przedzierzgną się w komentatora wydarzeń bieżących. Po wydaniu Hanemanna (1995) jego nazwisko poznała szeroka publiczność, zaczął on udzielać dużo więcej wywiadów niż wcześniej, wypowiadając się nie tylko na tematy związane $z$ literatura i kulturą, ale i $z$ aktualną sytuacją społeczno-polityczną ${ }^{57}$. Chwin pielęgnuje swój gdański rodowód tak samo pieczołowicie jak swoją biografię inteligencką: potomka warszawskiej rodziny kupieckiej, syna sanitariuszki z powstania 1944 roku, ucznia prof. Marii Janion ze słynnych seminariów $z$ lat siedemdziesiątych, partnera rozmów z Czesławem Miłoszem, poznanym dzięki prof. Janowi Błońskiemu. W jednym $z$ wywiadów mówi: „My, inteligenci, stoimy przed pytaniem: czy to społeczeństwo masowe, w którym żyjemy, jest w ogóle zainteresowane tym, żeby nasza mniejszość w jego

Łempicki, op. cit., s. 360.

A. Płaton ow, Wykop. Przeł. A. D rawicz. Kraków 1987.

J. Pilch, Moi mistrzowie. „Magazyn Literacki” 2013, nr 7/8: A jednak powieść. Dodatek do: „Tygodnika Powszechnego" 2013, nr 38, s. 7.

Ibidem.

Chwin został też w 2008 roku bohaterem wystawy $W$ pracowni pisarza w gdańskiej galerii Nadbałtyckiego Centrum Kultury. Była ona połączona częściowo z promocją książki S. C h w in a Dziennik dla dorosłych (Gdańsk 2008). 
obrębie istniała?"58 Niewątpliwie, pisarstwo Chwina krąży wokół tematu indywidualności, wokół podmiotu, który szuka umocnienia swej autonomii, swej niszowości, mniejszościowego poglądu - także w sytuacji konfliktu, dyskomfortu fundowanego przez nowoczesność. Podobny ton wybrzmiewa w wystapieniach medialnych Chwina, dla przykładu można przytoczyć bardzo charakterystyczne fragmenty jego wypowiedzi prasowych:

Założenie, że wszystko można wynegocjować, wydebatować, wydyskutować, jest niezgodne z realną rzeczywistością. Jak przygotowywać ludzi do życia w przestrzeni konfliktu - nie wiem.

Ale na pewno uczyć asertywności, woli samostanowienia, umiejętności przeciwstawiania się temu, co niesprawiedliwe, wzmacniać siłę charakteru, premiować odwagę cywilną i wolę niezależności $[. . .]^{59}$.

Kultura nastawiona na „edukację dla sukcesu” uczy żyć w kłamstwie. Zmusza do udawania człowieka sukcesu, zmusza do wstydu z niespełnienia ${ }^{60}$.

Nie inaczej jest $\mathrm{w}$ powieściach - i tu pobrzmiewa pasja publicysty, myśliciela zajmującego się przemianami świadomości, skutkami zmian cywilizacyjnych. Żywioł aktualności pociaga Chwina, $z$ jednej strony chętnie udziela on wywiadów, wyraża swoje opinie, ale $z$ drugiej strony - także bieżąca gorączka wydarzeń, afer, wkrada się do jego twórczości beletrystycznej, staje się kanwą opowieści, czego przykładem jest choćby Żona prezydenta (2005).

Chwin zdaje się pokazywać, że literatura nie stanowi zbioru martwych motywów, estetycznego składowiska wątków i problemów, ale może być elementem debaty publicznej. Na kartach jego prozy pojawiają się silne kobiety (Panna Ferbelin 〈2011〉), w prasie zaś pada zdecydowana deklaracja: „Jestem feminista” ${ }^{1}$. W powieściach Panna Ferbelin i Dolina Radości (2006) nie brakuje pytań o sacrum i Boga w obliczu zlaicyzowanego świata bez autorytetów i tematy te także często przewijają się w wypowiedziach medialnych Chwina. Nowoczesność funduje społeczeństwu nieuchronny pęd ku zagładzie - widać to wyraźnie w Dolinie Radości, gdzie narrację zdominowały rozważania moralno-filozoficzne, dla których punktem wyjścia - to spostrzeżenie Dariusza Nowackiego - jest ujawnienie katastrofy, która dokonała się właśnie u progu nowoczesności:

Chodzi o zniesienie opozycji między tym, co zewnętrzne, i tym, co wewnętrzne, poprzez zakwestionowanie tego drugiego wymiaru (jako iluzji metafizycznej). W powieści wielokrotnie powraca zdanie będące przetworzeniem myśli Nietzschego („Nie ma głębi, jest tylko powierzchnia”), a Chwin próbuje uchwycić i skatalogować rozliczne i nieodmiennie przykre konsekwencje utraty głębi ${ }^{62}$.

W tym świecie bez głębi rozgrywa się dramat tożsamości, gdzie „ja” gubi się wśród masek, pozorów oraz - co według Chwina najbardziej niebezpieczne i powszechne - nieprzejrzystości. Mowa jest także o sytuacji sztuki i artysty, o terrorze piękna, o płytkości tzw. światopoglądu naukowego. To żywioł bardziej publicystycz-

Bezbronny inteligent idzie na śmietnik. Ze S. Chwi n e m rozmawia M. Górlikowski. „Gazeta Wyborcza” 2013, nr z 30 XI - 1 XII, s. 24.

59 Ibidem.

60 S. Chwin, Tyrania optymizmu. „Plus Minus”. Dodatek do „Rzeczpospolitej” 2001, nr z 14 VII, s. D1.

61 S. Chwi n, Równo, czyli po połowie. „Gazeta Wyborcza” 2009, nr z 19 VI, s. 11.

62 D. Nowacki, Ryzykowna gra. Jw., 2006, nr z 31 X, s. 15. 
ny niż literacki, stawia on jednak literaturę w pozycji jednego z głosów walczących o rząd dusz, o rację i przekonania.

Politykę oraz historię ujętą nieco inaczej - jako obiekt rozmyślań - w jawnie literackiej wersji znaleźć można w ksiażce Chwina i jego żony, Krystyny Lars, Wspólna kapiel. To zbiór 104 miniatur, fragmenty ledwie napoczętych opowieści albo jakby mimochodem nakreślonych refleksji. Ostentacyjną literackość słychać już w tytułach poszczególnych notatek: Kamień mówi do Syzyfa, Sztylet mówi do Medei, Młody poeta $z$ Wilna robi ostatnie poprawki na rękopisie, Stefan Żeromski odbiera nagrodę Nobla, Rafat Wojaczek, czeterdziestosiedmioletni mężczyzna w skórzanym płaszczu, dziękuje lekarzowi pogotowia Janowi S. Jarosław Klejnocki zauważył w omówieniu tej książki: „Nie sposób oprzeć się wrażeniu, że zrodziła ją trauma polskich doświadczeń politycznych"63. Chwin i Lars nie zastanawiają się nad alternatywną wersją historii, nie poszukują jej i nie myślą nawet, by się o nią upomnieć. Próbują za to wydobyć na światło dzienne ukrytą inność, sąsiadującą z tym, co się zdarzyło. Zgodnie z opisem wydawcy na okładce temat książki, obiekt ich zainteresowania stanowi „zagadka ludzi, rzeczy i zdarzeń, dla których zabrakło miejsca w wielkim Scenariuszu" ${ }^{64}$. Jest to jednak opowieść niszowa, wystudiowana, przeznaczona dla odbiorcy nadążającego za intertekstualna grą wątkami literacko-biograficznymi, za ich przetworzeniem i dopisaniem ich nowej wersji.

Taka różnorodność w dorobku Chwina każe zastanowić się, do kogo pragnie on dotrzeć. O jakiego czytelnika mu chodzi? Czy autor Doliny Radości w ogóle go szuka? Czy jedynie - jako pisarz, moralista, badacz literatury, profesor - „chce zabrać głos" i dołączyć do szeregu znamienitych poprzedników, których zajmowały doniosłe sprawy i zasadnicze pytania? Niezależnie od tego, jakiej odpowiedzi udzielimy, a także od tego, jakiego znajdziemy czytelnika wpisanego w tekst, wracamy do zagadnienia indywidualizmu w twórczości Chwina. Skoro osobowość jego bohaterów zasadza się na tym, co wewnętrzne, to właśnie świat wewnętrzny będzie rozpalał jego pisarską ciekawość. Coś nieodkrytego, co porusza wyobraźnię, co kraży wokół zagadnienia znikania i śmierci, która unosi się nad światem małego Stefana w Krótkiej historii pewnego żartu (1991), jeszcze dobitniej brzmi w Hanemannie, a w Esther (1999) towarzyszy tytułowej bohaterce. Tematyka kresu, przewijająca się w narracji, zmusza do lektury refleksyjnej, skupionej - sprawia, że spowalnia galopujący świat realny, zatrzymuje go w poszukiwaniu różnic i podobieństw, intertekstualnych odwołań. „Dlaczego człowiek wybiera raczej życie niż śmierć?" - rozważanie tego pytania z Hanemanna ma ciagg dalszy w Esther. Ten, kto je zadaje, upomina się o wskazówkę, jak przeciwstawić się śmierci, jak radzić sobie z niepewnością życia. Chwin - jako pisarz nie może inaczej - swoją odpowiedź znajduje w literaturze, w opowieści, stawiającej kolejne pytania, które przychodzą $\mathrm{z}$ pomocą $\mathrm{w}$ próbach uporania się z zanikiem. Przemysław Czapliński zauważa:

Można nawet odnieść wrażenie, że autor zatrzymał się o krok od stwierdzenia, że Bóg też jest pisarzem - tylko okrutnym, kapryśnym, niecierpliwym, pisarzem, który jednym pociagnięciem pióra likwiduje wątki, uśmierca postaci, zamyka dzieje. Dlatego człowiek powinien opowiadać inaczej: powoli 
i starannie, zapewniając miejsce każdej rzeczy i nie gubiąc z narracyjnego pola widzenia żadnego bohatera.

[...] Literatura, zmieniając ślady, rzeczy, osoby i zdarzenia w szereg znaków na papierze, nadaje życiu trwałość 65 .

Ale śmierć, traktowana nie jako forma znikania, ale jako emblemat wolnej woli, fascynuje Chwina - pisarza i badacza kultury. Najlepszym tego dowodem sa dwie książki eseistyczne podejmujące temat samobójstwa: Samobójstwo jako doświadczenie wyobraźni (2010) oraz Samobójstwo i „grzech istnienia” (2013). We wstępie do pierwszej z nich Chwin tak przedstawia przyczyny swego zainteresowania tym zagadnieniem:

Od wielu lat [...] szukam odpowiedzi na pytanie, dlaczego ludzie nie chca żyć, jest to jedno z ważniejszych pytań mojej twórczości, ale w tej książce skupiam uwagę na szczególnym rodzaju powodów, które czasami ludzi popychają w śmierć. Nie są to - jak myślę - powody ani powszechne, ani dla większości zrozumiałe, choć mniej lub bardziej dotykają nas wszystkich. W każdym samobójstwie, nawet tym, którego przyczyny wydają się najtrywialniej konkretne, kryją się elementy „samobójstwa egzystencjalnego”, to znaczy takiego, do jakiego dochodzi „właściwie bez powodu”. Właśnie takie samobójstwo, którego główną przyczyną jest szczególnego rodzaju wtajemniczenie w kondycję ludzką, skutkujące radykalną niezgodą na istnienie, będzie mnie tu interesować najbardziej. W realnej rzeczywistości nie występuje ono nigdy w czystej postaci66.

Chwinowi chodzi więc o kondycję jednostki w dobie nowoczesnej, ale i o wzięcie odpowiedzialności za życie. Decyzja ta łączy się z pytaniem: czy na pewno chcielibyśmy się narodzić, wiedzac, jak wygląda świat? Instancją najodpowiedniejszą do udzielania odpowiedzi jest wyobraźnia, ocalająca dzięki swojej potencjalności - dzięki możliwości wyboru, o której tak pisze autor eseju:

Najciemniejszą doliną nie jest samobójstwo. Najciemniejszą doliną byłby świat, w którym samobójstwa nie moglibyśmy popełnić. Świat, w którym bylibyśmy zamknięci w żelaznej klatce istnienia na kłódkę - jak zamknięte są w niej zwierzęta - do ostatniego bólu, do ostatniego tchu, do ostatniej kropli udręczenia, bez względu na stopień egzystencjalnej wrażliwości naszego systemu nerwowego i stopień bolesności naszego - ukształtowanego przez naszą cielesność, biografię i kulturę - odczucia tego, co nie do zniesienia ${ }^{67}$.

Rozważania Chwina poświęcone samobójstwu wypływają z lektury Ciorana, otwierającej perspektywę ostentacyjnej bezradności. Życie - powiada Cioran - ocala tylko możliwość samobójstwa; ono gloryfikuje ludzką wolność:

Żelazne kajdany i duszna ciasnota tego świata mogą nas pozbawić wszystkiego, tylko nie możliwości zabicia się; a siła i duma płynące $z$ owej wolności przerastają ciężar, który nas przytłacza ${ }^{68}$.

Odniesienia do dzieł Ciorana pobrzmiewają i u Pilcha (którego razi zbyt elegancka Cioranowska fraza ${ }^{69}$ ), i u Stasiuka, zmierzającego w podróży opisanej

P. Cza plińs ki, Opowieść, siostra pamięci. „Polityka” 2000, nr 6, s. 47.

S. Chwi n, Samobójstwo jako doświadczenie wyobraźni. Gdańsk 2010, s. 5.

S. C h w i n, Dolina mroku, dolina światła. „Tygodnik Powszechny” 2010, nr 11, s. 24.

É. M. Ci or a n, Zarys rozkładu. Przeł. M. K ow a ls k a. Warszawa 2006, s. 53-54.

Zob. wypowiedź Pilcha w wywiadzie (S o b o lew s k a, op. cit., s. 72): „Cioran niczym innym się nie zajmował, tylko samobójstwem, i dojechał prawie do dziewięćdziesiątki. Jednak lepiej się go czyta, jak człowiek jest zdrowy. To ma elegancję i wyrazistość. Teraz, jak patrzę na niego przez pryzmat 
w ksiażce Jadac do Babadag do miejsca urodzenia rumuńskiego filozofa. U każdego jednak ujawnia się to w inny sposób. Pisarzy pociagga w światopoglądzie Ciorana asystemowość, model człowieka szukającego swojej prawdy poza nauką i sztuką, na obrzeżach i w zaprzeczonych emocjach, w cielesności. Pesymizm Ciorana pokazuje człowieka pozbawionego zdolności myślenia całościowego, bezradnie zatrzymanego w „tu i teraz”. Cioran otwiera perspektywę trwania, w którym nie ma rozwiązania (albo polega ono jedynie na możliwości targnięcia się na własne życie). Stasiuka ta postawa Ciorana zmusza do ruchu - do wędrówek myśli, do filtrowania uczuć, do refleksji nad czasem i nad losem. Świat w ruchu staje się dla autora Dukli obiektem zachwytu. Dla Chwina natomiast stanowi wyłącznie przykład postępującego upadku. Po raz kolejny potwierdza się, co trzeba podkreślić, że to doświadczenie egzystencjalne kształtuje pisarza. Dla Chwina - o czym on wielokrotnie mówił i pisał - takim przełomem życiowym i twórczym był widok pacyfikacji Gdańska przez milicję i wojsko w grudniu 1970. Bezpośrednia obserwacja owych wypadków pozwoliła temu pisarzowi doznać obezwładniającego poczucia, iż działa tam nieokreślona obca siła:

Grudzień to było dla mnie doświadczenie traumatyczne. Wyszedłem $\mathrm{z}$ tego głęboko poraniony. Coś się zachwiało w mojej wizji świata. Nie chodziło tylko o sprawy patriotyczno-niepodległościowo-martyrologiczne. Przeraziła mnie struktura zdarzeń, coś, co nazwałbym diabelstwem przypadku. [...]

Tamtego dnia wyszedłem na ulice Gdańska. To, co wtedy odczułem, to było dziwne doświadczenie Obecności. Nie umiałem powiedzieć, co to jest za Obecność i czyja, ale czułem ją bardzo silnie ${ }^{70}$.

Obcość jest znana, wręcz bliska Chwinowi, czaiła się już w jego dzieciństwie, kiedy zdał sobie sprawę $z$,wchodzenia w cudzy dom”, potem stała się niezbywalnym elementem życia w obcym-swoim kraju. Na tym poczuciu zasadza się także jego opowieść o Polsce, jaką snuje on w swojej prozie. Obcość jest siłą napędowa. Jej przejawy Chwin tropi w sobie, w swym otoczeniu, ale i w literaturze. Temu sposobowi lektury patronuje nieodmiennie Gombrowicz, polemizujacy z romantyzmem mesjańskim. Nie przypadkiem w roli naukowca Chwin zadebiutował właśnie esejem o autorze Trans-Atlantyku, porównując go z Mickiewiczem:

Po wielkiej przegranej wojnie polski emigrant - pierwszy we francuskiej, drugi w argentyńskiej stolicy - pisze swoja „Rzecz o Polsce”.

Pierwszy wzdycha „na paryskim bruku” do tych pól zielonych, gdzie dzięcielina, świerzop i gryka jak śnieg... Drugi wykrzywia twarz w szyderczym grymasie, zapraszając na „kluski stare na oleju grzechów" i opowiada o sobie, o przygodach swoich w Buenos Aires, o emigracji, o spotworniałym obliczu Polaka-pielgrzyma, jakby dopisując to, co zatajone w narodowej epopei ${ }^{71}$.

Chwin patrzy krytycznie na nurt literatury dającej prymat indywidualnemu spojrzeniu, pierwszeństwo polskości, która musi się określić wobec Europy i własnych mitów:

choroby, to przemawia do mnie trochę mniej. Zanim zacznie się zdanie, to już wiadomo, że będzie tak błyskotliwe, że coś okropnego".

70 Prześwity $w$ kamiennych tablicach. Ze S. Chwinem, pisarzem, rozmawia A. Franaszek. „Tygodnik Powszechny” 2006, nr 52, s. 12. Doświadczenie Grudnia 70 opisał Chwin w Dolinie Radości.

71 Chwin, „Trans-Atlantyk” wobec „Pana Tadeusza”, s. 97. 
Polak współczesny [...], według Gombrowicza, jest w takim stopniu pochłonięty myślami o zachowaniu swej narodowej tożsamości, że zapomina o tym, iż powinien zobaczyć w sobie nie tylko reprezentanta narodu, lecz także autonomiczną, niepowtarzalną i niezależną osobowość. Gwałtowne dążenie do pełnej identyfikacji z Formą Polską, dążenie do tego, by ani przez chwilę nie przestać „być Polakiem”, sprawia, że Polak ma słabe poczucie jednostkowości. A przed tym właśnie Gombrowicz się broni - odpowiadając postawą „dystansu wobec Polskości”72.

To lekcja, którą Chwin jako pisarz-inteligent będzie odrabiał w każdej swojej powieści, penetrując polskość poprzez to, co obce, na jej obrzeżach, i w tym, co próbuje ją rozbić, osłabić.

Z lektury twórczości wymienionych tu autorów: Pilcha, Andermana, Mentzla, Stasiuka i Chwina, wyłania się figura pisarza jako kogoś, kto zamieszkuje w opowieści. To literatura ocala ich podmiotowość. Autorzy ci są umocowani inaczej niż kiedyś: na obrzeżach, które nie stanowią marginesu, nie wywołują u nich kompleksu prowincji wobec centrum, ale są miejscami uprzywilejowanego określenia się w swoich korzeniach. Omawiani tu pisarze uczynili z literatury styl życia - nie tylko w znaczeniu zarobkowym czy zawodowym. Potrzebują jej w tym najbardziej elementarnym wymiarze - konstytuowania się własnego ,ja”. Powtarzanie wątków, tematów, fraz to strategia wiążąca wydarzenia: te z przeszłości i te uaktualniane w teraźniejszości. Świat książek nie stanowi rzeczywistości alternatywnej wobec realnej codzienności, ale pozwala ją ujarzmić, uczynić znośną. Czytanie traktują ci pisarze jako swoiste update w procesie ustanawiania więzi $\mathrm{z}$ otoczeniem i z samym sobą. Lektura umożliwia im uchwycenie ruchu myśli od powtórzenia (czegoś identycznego) do różnicy (tego, co odmienne) i zbadanie relacji między tożsamym a innym. Czytanie staje się sposobem bycia w świecie. To pozwala ustanowić nową prywatność, której obszarem komunikacji - ze sobą, z innym, z tradycją - będzie literatura korzystająca $\mathrm{z}$ biografii i przetwarzająca ją.

Abstract

KATARZYNA BUSZKOWSKA Institute of Literary Research of the Polish Academy of Sciences, Warsaw

ORCID: 0000-0003-0006-0954

\section{SETTLED IN LITERATURE ON READING WRITERS}

The paper demonstrates the way in which the contemporary writer is shaped by literature, especially by other writers. While reading becomes a mode of anchoring in the world, a recurring reading turns out to be not only a place of forming the writer's identity, but also of the themes which figure their biography and creativity. The process of creation, the artist's maturation and special importance of art for such writers as Jerzy Pilch, Janusz Anderman, Zbigniew Mentzel, Stefan Chwin or Andrzej Stasiuk are fundamentals of spiritual life. What emerges from reading pieces by the mentioned men of letters is the figure of the writer who inhabits the story. For them literature has become a way of life, not only in financial or professional aspect. They need literature in its most fundamental meaning to construct their own "I". The world of books is not an alternative to everyday realty but it allows to subjugate it and to make it bearable. 